\title{
Providing Built Environment Students with the Necessary Skills for Employment: Finding the Required Soft Skills
}

\author{
Pat Crawford, Robert Dalton \\ School of Planning, Design and Construction, Michigan State University, East Lansing, USA \\ Email: crawf203@msu.edu, daltonr1@msu.edu
}

Received 24 February 2016; accepted 27 March 2016; published 30 March 2016

Copyright (C) 2016 by authors and Scientific Research Publishing Inc.

This work is licensed under the Creative Commons Attribution International License (CC BY). http://creativecommons.org/licenses/by/4.0/

(c) $\underset{\mathrm{EY}}{\mathrm{i}}$ Open Access

\begin{abstract}
As the costs of education, class sizes, and competition in a post-recession work force grow, universities will explore the ways in which students may graduate with high opportunities for employment in their chosen field. Students in the Built Environment (B.E.) are graduating from accredited programs, but what skills beyond technical understanding do employers wish to have in their entry level employees? A survey of $\mathbf{8 1 2 4}$ respondents of employers, alum, faculty and students allowed these stakeholders to rank order seven soft skills and seven characteristics within each soft skill. This study explores the ways in which the B.E. field ranks the skills and characteristics in comparison to seven other professional fields. The B.E. respondents rank order the soft skills as: communication, decision-making, self-management, experiences, teamwork, professionalism, and leadership. Utilizing ordinal regression, it was found that B.E. respondents rank creative solutions, applying technology, cross disciplinary and international experiences as more important than other fields. Many of the differences are attributed to the need for those in the built environment to think creatively and work collaboratively. The findings can inform educational curriculum to match soft skill training with the professional path of their students.
\end{abstract}

\section{Keywords}

Soft Skills, Education, Employability Skills

\section{Introduction}

The combination of economic recession and rising cost of education in the United States creates a challenging environment for the next generation of Built Environment (B.E.) Professionals. Between 2006 and 2012, the av- 
erage tuition cost at public four-year universities has increased 34\% (average 5.6\% per year) to offset decreased government support (Armario, 2012). In this competitive and global job market, with up to 6 applications for every job in Landscape Architecture and an unemployment rate over $13 \%$ for new architecture graduates, college grads are grappling with how to set themselves apart and secure entry level positions (Land 8 Lounge, 2011; Rampell, 2012). Securing employment in the B.E. professions will also mean going to where the work isgrowing urban and suburban environments (Occupational Outlook Handbook, 2016). Many of these built environment professions are increasingly practicing urban to keep up with housing demographic and cultural shifts, forcing a shift in traditional office practices and philosophies (Gallagher, 2013; Ellin, 2006).

The US Bureau for Labor Statistics does provide hope for young professionals with a projected employment increase at pace or above average for a host of allied professions including architecture, landscape architecture, urban design, surveying, and civil engineering (U.S. Bureau of Labor Statistics, 2016). Bachelor's degrees in Technical/Professional Fields are projected to be among the most secure majors for employment after earning a Bachelor's degree (Gardner et al., 2011). Facing the realities of economics and new demands of the $21^{\text {st }}$ century, university administrators and faculty are exploring how they can revitalize education and make their graduates more competitive in the job market. It's more than just a matter of professional or technical knowledge; the soft skills of communication, decision-making, self-management and teamwork are critical skills; employers are looking for in applicants (Crawford et al., 2011b).

Employers and faculty are aware of the need to complement professional and technical skills with soft skills. What is missing is where to focus scarce time and resources. Which is the most important? Which can wait until later? Are the priorities the same across different professions or industry sectors? This study explores the priorities of soft skills for entry-level employment in Built Environment professions with a ranking survey. Ranking is a common means in consumer behavior research to define priorities when respondents have limited time or budget constraints (Foxall et al., 2006). These priorities are compared to other employment sectors in agriculture and natural resources industries.

\section{Literature Review}

Employers are looking at applicants across a range of majors to find the right skills and abilities for their organization (Gardner et al., 2011). When businesses come to college career fairs looking to hire, they are in fact looking for a broad set of skills that include not only strong technical expertise but also "soft skills" in candidates (Doyle, 2011). Soft skills are those skills needed in all lines of employment, rather than specific disciplinary, or technical, skills of a profession (Robinson, 2006).

The soft skills include many different attributes and characteristics, such as adaptability (Plamondon et al., 2000), proper communication (Mallet-Hammer, 2005), and working with others (Conference Board of Canada, 2000). Flexibility, including the use of feedback and critique and engaging all opinions, goes hand in hand with adaptability (Trilling \& Fadel, 2009).

Many of the broad soft skills contain a range of descriptive elements and several taxonomies have been created. For example, adaptability, includes handling emergencies in crisis situations, handling work stress, solving problems creatively, learning work tasks, technologies, and procedures, dealing with uncertain and unpredictable work situations, demonstrating interpersonal adaptability, demonstrating cultural adaptability, and demonstrating physically oriented adaptability (Plamandon et al., 2000). Communication includes reading comprehension as well as oral and written attributes (Conference Board of Canada, 2000). General competencies have been articulated as: 1) resources (being able to manage time, spending, and people), 2) information (apprehending and comprehending), 3) interpersonal (working with and for well with others), 4) systems (improving the organizational technological performance), and 5) technology (self-managing technology skills), (SCANS, 2000).

Soft skills hold a high priority for employment across the geo-political barriers (Commonwealth of Australia, 2009; UK Commission for Employment and Skills, 2009; Griesel \& Parker, 2009; SCANS, 2000). The United States generally speaks one language, but outside of the United States many countries often similar in size and population to one state. Many of these countries bring with them their own language and culture. As such, oral communication and foreign language skills rate high in priority (Arocena, Nunez, \& Villanueva, 2007; Zaharim et al., 2009). In contrast, employers within the United States often see little value in an undergraduate's study abroad experience (Gardner, 2007; Scholar Ship, 2007). 
In 2011, the US Association of Public and Land-grant Universities (APLU) took on the question of identifying soft skill (employability) priorities for new graduates in Agriculture and Natural Resources related disciplines. Their work began from a question that Universities may not preparing students with the basic soft skills needed for entry level employment. As the a National organization located in Washington, DC, with 221 member institutions (encompassing public, land-grand and state universities) and over 3.5 million undergraduate students (Fink, 2011; APLU, 2007-2011), the APLU is uniquely situated to bring people together to address the question. For the 2011 APLU National Academic Programs Summit, lead by committee Chair, Dr. Josef Broder (University of Georgia), the theme was "Creating Change: Reforming Curricula for a 21st Century Education." (see http://www.aplu.org/page.aspx?pid=1992 for Summit information). The Summit goal is to "... focus on curricular reform with respect to what we teach. While our colleges are well-regarded for their teaching of the disciplines and technical skills, employers often take our institutions (and higher education as a whole) to task for not preparing students with transferable skills beyond the disciplines” (APLU, 2011).

To address the Summit goal, a Comparative Analysis of Soft Skills (CASS) survey was created to explore the similarities and differences between how students, faculty, alum and employers rank order soft skills. In addition to the committee Chair, the CASS team included Ms. Wendy Fink (director of Academic Programs Section (APS), APLU), Drs. Pat Crawford and Suzanne Lang (faculty at Michigan State University) and two students, Mr. Robert Dalton and Ms. Laura Fielitz (graduate and undergraduate students, respectively, at Michigan State University). Survey findings were presented by the team at the APLU Summit in Indianapolis, IN (Crawford et al., 2011a).

Using a cluster analysis process of soft skills identified in the literature, the CASS team organized the skills into seven clusters, with seven descriptive characteristics each. A priority ranking system was used for survey respondents to rank the clusters and then the descriptive characteristics within each cluster. The forced ranking system pushed respondents to provide a ranking, of most to least important, rather than being able to rank all or many of the skills equally. Responses were received from 31 Universities across the US. The 8124 responses included: 2699 students, 898 faculty, 4266 alum, and 291 employers. Value perceptions of the soft skills created a basis for beginning the conversation at the APS-APLU Summit. Communication, Decision-Making and SelfManagement were the top three skill clusters, as ranked by the employers, and Leadership was ranked $7^{\text {th }}$ (Crawford et al., 2011a). It was noted at the Summit that while the rankings help to identify high priority which skills could be focused on at the University level for education and training, all of the soft skills are important.

\section{Methodology}

\subsection{Research Design}

This work is a new line of inquiry building off the APLU Report Comparability of Soft Skills: What is Important for New Graduates? (Crawford et al., 2011b). The authors were part of the CASS research team and the previous summary information sets the stage for the new in-depth analysis presented in this article focusing on soft skill values of those in Built Environment professions.

\subsection{Data Analysis}

The Comparability of Soft Skills: Data Set (Crawford et al., 2011c) is used for analysis with the Statistical Package for Social Science 19 (SPSS-IBM Statistics Software Editor). For this study the data is explored for significant differences of ranking of the soft skills by the B.E. field compared to the other Fields using ordinal regression. This technique is selected due to the forced ranking of data used in the CASS study which places an "order" on the variables but does not indicate a scale or distance between the variables (IBM, 2011). In this study, the field type is designated as the independent variables. With $45+$ possible responses for employment types with in agriculture and natural resources, employment types were coded into eight Fields for demographic reporting in the 2011 CASS report. The independent variables are:

1) Agricultural Services;

2) Education and Knowledge Development;

3) Built Environment;

4) Product Creation and Manufacturing;

5) Government; 
6) Human and Animal Health and Medicinal Services;

7) Service Industry;

8) Other.

The soft skill clusters and characteristics are designated as the dependent variables (see Appendix 1: Field Soft Skill Cluster and Characteristic Mean, ordered by B.E. Rank, Tables A1-A8). The analysis was run 56 times, once for each dependent variable (7 clusters plus 49 characteristics). The findings include significant differences from the Built Environment compared to the other Fields and P values equal to or less than 0.05 are considered significant.

\section{Findings}

The final tally of responses used for this study is 7548. (576 cases with no employment response removed). The responses are distributed across the eight Fields with $13.73 \%$ B.E., fourth highest in response frequency (see Table 1: Response rate by field).

The B.E. respondents rank order the soft skill clusters with communication, decision-making/problem solving and self-management as the most important with leadership as the least important (see Table 2: B.E. Soft Skill Cluster Mean Ranking). The B.E. order of rank mirrors the combined Non-B.E. mean rank. However, B.E. respondents place a slightly lesser mean value on communication and greater value on decision-making and selfmanagement. At the lowest rank, B.E. place a lower mean value on leadership than their counterparts. Appendix 1 (Tables A1-A8) includes the rank order of B.E. for the overall clusters and each characteristic, as ordered by the B.E. respondents.

Table 1. Response rate by field.

\begin{tabular}{ccc}
\hline Field & N & Percent \\
\hline Agricultural Services & 1472 & $19.50 \%$ \\
Education and Knowledge Development & 1455 & $19.28 \%$ \\
Human and Animal Health and Medicinal Services & 1077 & $14.27 \%$ \\
Built Environment & 1036 & $13.73 \%$ \\
Service Industry & 977 & $12.94 \%$ \\
Other & 774 & $10.25 \%$ \\
Government & 440 & $5.83 \%$ \\
Troduct Creation and Manufacturing & 317 & $4.20 \%$ \\
Total & 7548 & $100 \%$ \\
\hline
\end{tabular}

Table 2. Built environment soft skill mean ranking.

\begin{tabular}{|c|c|c|c|c|c|c|}
\hline \multirow{2}{*}{ Soft Skill Cluster } & \multicolumn{3}{|c|}{ B.E. } & \multicolumn{3}{|c|}{ Non-B.E. } \\
\hline & Mean & $\mathrm{N}$ & Std Dev & Mean & $\mathrm{N}$ & Std Dev \\
\hline Communication & 3.0995 & 915 & 1.7868 & 2.9543 & 5798 & 1.6473 \\
\hline DM/PS & 3.1783 & 914 & 1.7865 & 3.4719 & 5806 & 1.8499 \\
\hline Self-Management & 6.6410 & 908 & 1.8926 & 3.7209 & 5786 & 1.9249 \\
\hline Experiences & 4.0120 & 913 & 2.2534 & 4.1883 & 5779 & 2.2944 \\
\hline Teamwork & 4.2177 & 905 & 1.7868 & 4.3183 & 5784 & 1.8029 \\
\hline Professionalism & 4.6501 & 906 & 1.8550 & 4.5332 & 5780 & 1.8795 \\
\hline Leadership & 5.1501 & 913 & 1.7797 & 4.7738 & 5768 & 1.9063 \\
\hline
\end{tabular}


Significant differences appear when comparing B.E. to each of the Fields independently. In the Decisionmaking/Problem-Solving and Leadership clusters B.E. significantly differs with six of the seven Fields in priority ranking (Figure 1). B.E. rank Decision-Making higher and Leadership lower than the other Fields. Significant Differences for each of the Fields and cluster characteristics are provided in Appendix 2 (Tables A9-A16).

Within each cluster, seven descriptive characteristics give deeper meaning to the cluster. Significant differences between B.E. rankings and the other Fields emerged ( 7 fields $\times 7$ characteristics $=49$ comparisons per cluster to B.E.). The cluster with the most differences is Communication with almost half of the possible comparisons to the other Fields significant (Table 3). The two Communication characteristics with the highest rate of significant difference are effective written communications and asking good questions. B.E. respondents tend to prioritize these characteristics. Self-Management and Experience clusters tie for the second most number of significant differences. In Self-Management, B.E. respondents place a higher priority on adapting and applying appropriate technology and on Experiences with a cross cultural component. The Leadership cluster has significant differences in one-third of the Field comparisons. B.E. respondents prioritize leading and motiving others lower than five of the comparison Fields. Five characteristics have no significant difference between B.E. and the comparison Fields. These are transferring knowledge across situations; well-developed ethic, integrity and loyalty; understand role, realistic career expectations; maintain appropriate décor and demeanor; and recognize when to lead and when to follow.

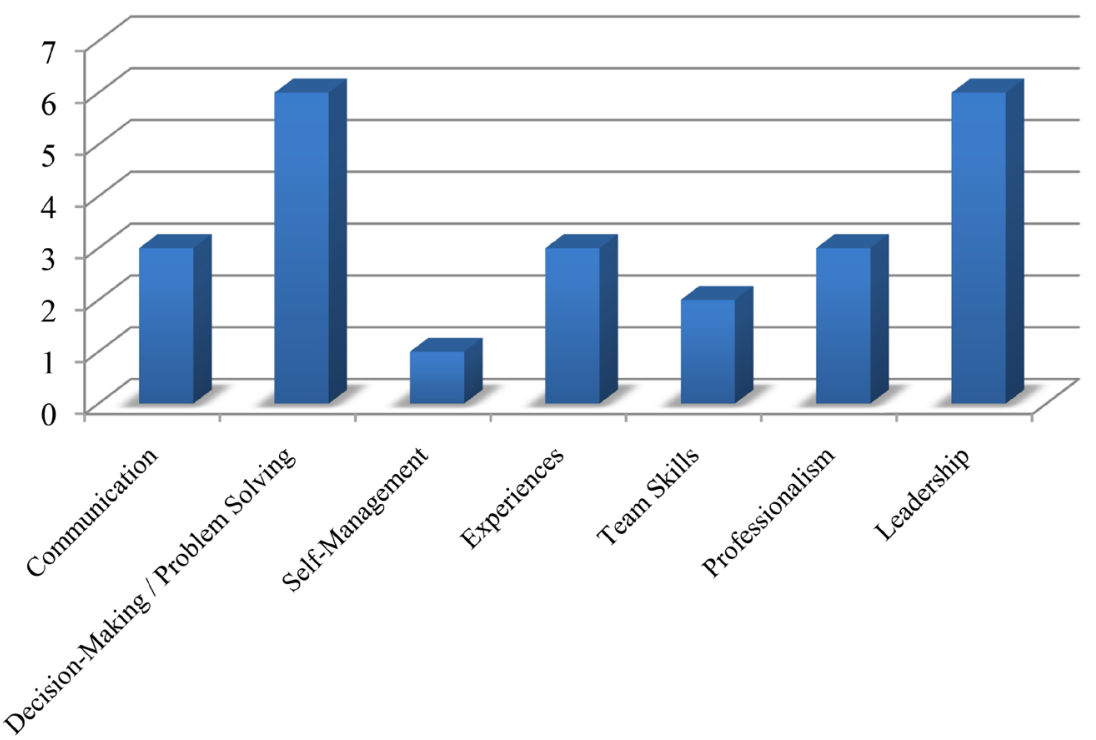

Figure 1. Significant difference occurrences for B.E. compared to the other fields for the core skill rank order.

Table 3. Significant difference occurrences by characteristic.

\begin{tabular}{cccccccccc}
\hline \multirow{2}{*}{ Cluster } & \multicolumn{7}{c}{ Characteristic/Number of Sig/Differences to B.E. } \\
\cline { 2 - 8 } & Total & Char 1 & Char 2 & Char 3 & Char 4 & Char 5 & Char 6 & Char 7 \\
\hline Communication & $24 / 49(49 \%)$ & 3 & 1 & 2 & 4 & 5 & 5 & 4 \\
DM/PS & $14 / 49(29 \%)$ & 2 & 1 & 0 & 1 & 3 & 3 & 4 \\
Self-Management & $22 / 49(45 \%)$ & 4 & 3 & 0 & 3 & 3 & 5 & 4 \\
Experiences & $22 / 49(45 \%)$ & 4 & 6 & 2 & 4 & 2 & 2 & 2 \\
Teamwork & $13 / 49(27 \%)$ & 1 & 1 & 3 & 1 & 2 & 1 & 4 \\
Professionalism & $13 / 49(27 \%)$ & 3 & 2 & 4 & 0 & 0 & 2 & 2 \\
Leadership & $16 / 49(33 \%)$ & 3 & 0 & 1 & 1 & 3 & 3 & 5 \\
\hline
\end{tabular}




\section{Discussion}

\subsection{Core Skills}

B.E. and all other fields rank the core skills in the same order. Both B.E. and Non-B.E. groups put a priority on the base clusters of communication, decision-making/problem-solving, and self-management instead of the advanced clusters such as professionalism and leadership. With the second largest range between the most and least prioritized skills and the second lowest mean standard deviation of the eight fields, B.E. have a clear delineation of prioritized skill clusters. B.E., however, does not delineate between their top two clusters (Communication and Decision-Making/Problem-Solving) as much as the other eight clusters, placing a significant higher emphasis on the second cluster than six of the seven fields.

Experiences, with the highest standard deviation of the seven clusters, is a polarizing cluster for the B.E. as $20.6 \%$ say it is the most important, while $17.7 \%$ say it is the least important. This could reflect either the great difference in quality of the student experiences or a great difference in the student's ability to communicate their experiences and transfer their learning into their new employment. B.E. places the second highest emphasis on Experiences, significantly differing from Agricultural Services, the Service Industry, and the Other fields.

B.E. places the least emphasis on Leadership, significantly differing from all fields except the government. Most firms within the B.E. cluster have a clear hierarchy of job titles, from designer through Project Manager and Associate. The entry-level employees are not selected for their leadership qualities, but can develop these skills overtime with a firm or organization.

\subsection{Communication}

The B.E. professions rank order the communication characteristics as:

1) Listen effectively;

2) Communicate accurately and concisely;

3) Effective oral communications;

4) Communicate pleasantly and professionally;

5) Effective written communications;

6) Ask good questions;

7) Communicate appropriately and professionally using social media.

Listening effectively and the ability to communicate accurately and concisely are the top two skills for each field, though only three of the eight (including B.E.) rank listening as number one. With an average range of 0.07 for the two means, one of these skills may easily become the most important with any given employer. While the average ranking has listening first, more individuals in the B.E. field rank communicating Accurately and Concisely as the most important in comparison to listening. This may relate to communicating across different disciplines within a project team and presenting design or construction documentation to clients.

Across all fields, oral communication outranks written communication. B.E. places the second least emphasis on oral communication and the second highest emphasis on writing skills of the eight fields. In addition to practicing through presentations in the University setting, B.E. can set itself apart from the other fields with enhanced writing skills to describe designs as well as technical writing for construction and ecology.

Asking good questions and using social media are the least important skills, regardless of the field. B.E., however, ranks Ask Good Questions as more important than six of the other seven fields, significantly differing from five. Asking questions is a foundational component of the design and planning process. Given the breadth of B.E. as field, universities cannot teach every skill needed but can teach their graduates how to understand what they do not know and how to find future solutions.

\subsection{Decision-Making/Problem-Solving}

The B.E. field rank orders the Decision-Making/Problem Solving characteristics as:

1) Identify and analyze problems;

2) Take effective and appropriate action;

3) Transfer knowledge across situations;

4) Realize the effect of decisions;

5) Creative and have innovative solutions; 
6) Engage in life-long learning;

7) Think abstractly about problems.

The top four skills (Identify and Analyze Problems, Take Effective and Appropriate Action, Transfer Knowledge from One Situation to Another, and Realize the Effect of Decisions) have few significant differences. In fact, the B.E. means differ from the Non-B.E. mean an average of 0.07 for the top four skills. The first three characteristics are skills inherent in the planning, design, and construction process. B.E. does not emphasize the importance of Realize the Effect of Decisions as much as six of the other Fields. Many entry level B.E. positions are an apprenticeship and final decisions are by more senior or licensed (depending on country or state regulations) team members.

Creative and Innovative solutions spikes in popularity against the other Fields as the B.E. ranks it with significant greater importance than the Product Manufacturers, Government, and Health Services. Working with a set of program elements from a client that may exceed the budget, the B.E. field must continual think creatively to meet the needs of the client in unique ways to deliver the product on time and under budget. Engaging in Life-Long Learning is not as highly ranked with the B.E. field. This may reflect a higher priority on the creative solutions, or an assumption that entry levels will continue education to earn their license. B.E. puts the highest importance on the ability to Think Abstractly in comparison to the other Fields, again proving that working and thinking outside of the box sets B.E. apart from the other Fields.

\subsection{Self-Management}

The B.E. field rank orders the self-management characteristics as:

1) Efficient and effective work habits;

2) Self-starting;

3) Well-developed ethic, integrity and loyalty;

4) Work well under pressure;

5) Sense of urgency to complete tasks;

6) Adapt and apply appropriate technology;

7) Dedication to continued professional development.

Efficient and Effective Work Habits leads the Self-Management cluster with a mean score far ahead of the other characteristics. The B.E. field values this characteristic the most of the eight Fields, significantly differing from the Product Manufacturers, the Service Industry, and the Other field. Overall, Efficient and Effective Work Habits has the lowest standard deviation, setting a unity of opinion across all survey respondents.

B.E. need their products done well as the top priority, while the time-management characteristics (Work Well Under Pressure and Sense of Urgency to Address and Complete Tasks) rank further down the list as the fourth and fifth most important characteristics respectively. B.E. places the second least emphasis on Work Well Under Pressure of the eight Fields.

Though it is the sixth ranked skill characteristic, Adapt and Apply Appropriate Technology is significantly more important for B.E. than five of the other characteristics. As new technologies emerge with more advanced features, B.E. firms expect their young hires to efficiently use the correct software for design, sales, and reports.

\subsection{Experiences}

The B.E. rank orders the Experiences as:

1) Related work or internship experiences;

2) Cross disciplinary experiences;

3) Leadership experiences;

4) Teamwork experiences;

5) Project management experiences;

6) Community engagement experiences;

7) International experiences.

Overall, B.E. significantly differ from Agricultural Services on six of the seven skill characteristics. Over 25\% of all differences within the Experience cluster occur with the Agricultural Services.

Related Work or Internship Experience is the most important characteristic among all eight Fields, but B.E. puts significantly less importance on it than the Agricultural Services, Government, Health Services, and the 
Service Industry. In comparison to other new employees, B.E. are not bringing skills from past work experiences to their entry level employment. This may be a reflection of the required apprenticeship for B.E. fields or the impact of the recession that disabled many students from attaining quality internship experiences.

Though a virtual tie with Product Manufacturers, B.E. far out rank Cross Disciplinary Experience when compared to all other Fields. The B.E. professions, such as architects, builders, designers, artists, engineers, foresters, horticulturalists, planners, ecologists, and soil scientists, are closely allied in the professional world. While siloes in education may keep each major working independently, entry level employees should be able to: 1) work with, 2) respect, and 3) peak the basic jargon of each group of professionals.

International Experience ranks last with every field, and B.E. falls in the middle of the Fields' means. Students with an effective study abroad or international living experience grow personally, but are not coming into the work force with the ability to articulate what have learned or translate the knowledge between settings.

\subsection{Teamwork}

The B.E. rank orders the teamwork skills as:

1) Productive as a team member;

2) Punctual and meets deadlines;

3) Positive and encouraging attitude;

4) Maintains accountability to the team;

5) Work with multiple approaches;

6) Share ideas to multiple audiences;

7) Aware and sensitive to diversity.

Ten of the thirteen significant differences among the B.E. and the other Fields are among Education, Health Services, and Service Industry (nearly 25\% of all differences occur with the Service Industry).

Each Field ranks Productive as a Team Member and Punctual and Meets Deadlines as the most important characteristics. B.E., however, places a stronger emphasis than all other Fields on being a productive team member, significantly more than the Service Industry. Entry-level employees will be expected to bring their skills to a team and complete their assignments on time.

B.E. places much less importance on the attitude of the employee in comparison to the other all other Fields except the Government. While this characteristic is still the third most important among the B.E., more emphasis is placed on the quality of the work.

As the B.E. stress cross-disciplinary experience in the previous cluster, Work with Multiple Approaches also ranks as more important compared to all other Fields except for the Government. Entry-level employees within B.E. will be expected to think differently and evolve planning and design ideas from abstract concepts to construction. B.E. place the least value on Share Ideas to Multiple Audiences in comparison to the other Fields, demonstrating that entry level employees may work on multiple types of projects but may not present the finished product until more seasoned.

\subsection{Professionalism}

The B.E. field rank orders the Professionalism characteristics as:

1) Effective relationships with customers, businesses and the public;

2) Accept critique and direction in the work place;

3) Trustworthy with sensitive information;

4) Understand role, realistic career expectations;

5) Maintain appropriate decor and demeanor;

6) Select mentor and acceptance of advice;

7) Deal effectively with ambiguity.

Though Effective Relationships with the Customers, Businesses, and the Public is the most important Professionalism characteristic, B.E. places the second least importance on it among the eight Fields. This further demonstrates that entry-level employees will work in house with various disciplines, but not sell the final product. Instead, the B.E. places more emphasis on Accept and Apply Critique and Direction in the Work Place. Selecting the appropriate mentor, however, is not as highly valued in an entry-level employee. B.E. employers look for candidates who can work well and effectively, but may not have time to mentor a young adult. However, as the 
B.E. have placed the second most emphasis on mentors, the new hires have a better chance of finding a mentor in B.E. than in other field types. Overall, B.E. tends to rank in the middle of the eight Fields and have a small gap between the most and least important characteristics, demonstrating ambiguity in the cluster.

\subsection{Leadership}

The B.E. field rank orders the Leadership characteristics as:

1) See the "big picture" and think strategically;

2) Recognize when to lead and when to follow;

3) Recognize and deal constructively with conflict;

4) Respect and acknowledge others contributions;

5) Motivate and lead others;

6) Build professional relationships;

7) Recognize change is needed and lead the change effort.

In comparison to other Fields, B.E. stresses the importance of personal relationships over business relationships for an entry-level employee. B.E. places the second most emphasis on Motivate and Lead Others (a personal relationship trait), while putting the least emphasis on Build Professional Relationships. The last ranked characteristic is Recognize Change is Needed and Lead the Change Effort. B.E. places the second lowest emphasis on this characteristic, further demonstrating the new employees should not lead to make drastic changes for the organization but instead develop leadership with tenure.

\section{Conclusion}

Entry level, built environment professionals should master the highest ranking soft skill clusters: communication, decision-making/problem solving (DM/PS), and self-management. Successful learning of these foundational, core skills may permit the professional to continue to learn the higher order skills such as professionalism and leadership.

Communication, the most important cluster, will be the key to success, especially as teams integrate their skills to solve problems in the urban, built environment. Tools such as the Last Planner ${ }^{\circledR}$ System permit changes in construction scheduling, but require the practitioners to come together in person. Listening and clear, concise communication, the top two characteristics, transcend in-person communication, written briefs, phone calls, and email.

Though DMPS is the second most important cluster, its top four characteristics are recognized without many significant differences across the professions. Urban, built environment professionals should acquire the ability to identify problems and take appropriate action. This includes the foresight to understand early when a project will likely face opposition in zoning or other regulations or when contractors may not build to exact specifications. In such instances, a professional with well-developed soft skills can effectively work with planners, designers, and builders.

While efficient and effective work habits are important in every profession, decreasing budgets and expanding scopes are demanding top-tier work from the entry-level employees in the built environment. With less emphasis on working well under pressure as compared to other fields, built environment professionals will likely need the work done well the first time rather than spending resources on re-work. If this is the priority of an office, senior level practitioner should be sure to give the appropriate amount and scale of work to the entry-level employees and use time early to help the entry-level worker to comprehend the breadth and depth of skills for the task ahead.

B.E. respondents rank asking good questions, creative and innovative solutions, applying technology, crossdisciplinary and international experiences as more important than other Fields. The authors believe that many of the differences are attributed to the value of creative and strategic thinking and the understanding of design or system processes in B.E. As urban problems grow in magnitude, entry-level employees should focus on the top tier core skills rather than less prioritized skills, such as leadership. Leadership will come in their role in the office, and will be a tremendous learning experience. To be best prepared for the soft skills required in leadership, one should already develop those characteristics within communication.

These soft skills represent those universally applicable across all employment types. The built environment provides the opportunity to study soft skills very important to itself, such as visually inspecting built sites and 
graphic communication. Missing data from the original survey's attrition rate may limit generalizability of this study (McKnight et al., 2007). Repeated studies demonstrate, though, that all soft skills are important. Future work may investigate the differences in soft skills priorities between those who practice urban and that who practice rural in the built environment. For example, does practicing in dense areas affect the importance of listening or communication in general? To study the built environment ranked priorities that limit missing data, the research team recommends a targeted sample to reduce attrition rates in their study. Following this study of ranked skills, additional research can investigate the methods of preparing built environment students' soft skills in the classroom and assessing built environment recent graduates' soft skill preparedness for entry-level soft skill needs.

\section{Acknowledgements}

Thank you to the Association of Public and Land-grant Universities, University-Industry Consortium, Michigan State University and MSU AgBio for this data set and support.

This work is an abridged version of one of the author's thesis submitted in partial fulfillment of the requirements for a Master of Arts in Environment Design at Michigan State University. The thesis is entitled discerning priorities for soft skill development for environmental and natural resource undergraduate students.

\section{References}

Armario, C. (2012). Average Cost of Four-Year University up 15\%. USA Today.

http://usatoday30.usatoday.com/money/economy/story/2012-06-13/college-costs-surge/55568278/1

APLU (2011). National Academic Programs Summit. Washington DC: APLU.

APLU (2007-2011). Welcome to APLU. Washington DC: APLU. http://www.aplu.org/page.aspx?pid=203

Arocena, P., Nunez, I., \& Villanueva, M. (2007). The Effect of Enhancing Workers' Employability on Small and Medium Enterprises: Evidence from Spain. Small Business Economics, 29, 191-201. http://dx.doi.org/10.1007/s11187-006-6712-7

UK Commission for Employment and Skills (2009). The Employability Challenge. Adwick Park: UK Commission for Employment and Skills.

The Commonwealth of Australia (2009). Employability Skills and Workplace Culture in Australia. East Perth: Department of Education and Training.

Conference Board of Canada (2000). Employabilty Skills 2000+. Ottawa, CA: Conference Board of Canada.

Crawford, P., Lang, S., Fink, W., Dalton, R., \& Fielitz, L. (2011a). Comparability Analysis of Soft Skills: What Is Important for New Graduates? Paper Presented at the APLU Academic Programs Summit, Indianapolis.

Crawford, P., Lang, S., Fink, W., Dalton, R., \& Fielitz, L. (2011b). Comparability Analysis of Soft Skills: What is Important for New Graduates? Washington DC: APLU.

http://www.aplu.org/document.doc?id=3414

Crawford, P., Lang, S., Fink, W., Dalton, R., \& Fielitz, L. (2011c). Comparability of Soft Skills: Data Set. Washington DC: Association of Public and Land-Grant Universities.

Doyle, T. (2011). Learner Centered Teaching: Putting the Research in Learning into Practice. Sterling, VA: Stylus Publishing, LLC.

Ellin, N. (2006). Integral Urbanism. New York, London: Routledge and Taylor Francis Group.

Fink, W. (2011). The Importance of Soft Skills to Employers. AgWired: News from the World of Agribusiness.

Foxall, G. R., Oliveira-Castro, J. M., James, V. K., Yani-de-Soriano, M. M., \& Sigudssson, V. (2006). Consumer Behavior Anaylsis and Social Marketing: The Case of Environmental Conservation. Behavior and Social Issues, 15, 101-124. http://dx.doi.org/10.5210/bsi.v15i1.338

Gallagher, L. (2013). The End of the Suburbs. New York: Penguin.

Gardner, P., Render, I., \& Sciarini, N. (2011). Recruiting Trends 2010-2011. East Lansing, MI: Michigan State University.

Gardner, P. (2007). Moving Up or Moving Out of the Company? Factors That Influence the Promoting or Firing of New College Hires. East Lansing, MI: Michigan State University.

Griesel, H., \& Parker, B. (2009). Graduate Attributes: A Baseline Study on South African Graduates from the Perspective of Employers. Pretoria: Higher Education South Africa \& the South African Qualifications Authority.

IBM Corporation (2011). IBM Statistical Package for the Social Sciences 19. Armonk, NY: IBM.

Land8Lounge (2011). The Unemployment Rate for Landscape Architects/Designers. 
http://land8.com/forum/topics/the-unemployment-rate-for-landscape-architects-designers

McKnight, P. E., McKnight, K. M., Sidani, S., \& Figueredo, A. J. (2007). Missing Data: A Gentle Introduction. New York: Guilford Press.

Occupational Outlook Handbook (2016). http://www.bls.gov/ooh/

Plamondon, K. E., Donovan, M. A., Pulakos, E. D., \& Arad, S. (2000). Adaptability in the Workplace: Development of a Taxonomy of Adaptive Performance. Journal of Applied Psychology, 85, 612-624. http://dx.doi.org/10.1037/0021-9010.85.4.612

Rampell, C. (2012). Want a Job: Go to College, and Don’t Major in Architecture. New York Times, 5 January 2012.

Robinson, J. S. (2006). Graduates’ and Employers’ Perceptions of Entry-Level Employability Skills Needed by Agriculture, Food and Natural Resources Graduates. PhD Thesis, Columbia, MO: University of Missouri.

Secretary's Commission on Achieving Necessary Skills (2000). Skills and Tasks for Jobs: A SCANS Report for America 2000. Washington DC: US Department of Labor.

Scholar Ship (2007). Study Abroad Boosts Employability Say Global HR Execs in New Study. 9 April 2007. http://old.goinglobal.com/newsletter_atricles/june07_general_study.asp

Trilling, B., \& Fidel, C. (2009). 21st Century Skills: Learning for Life in Our Times. San Francisco, CA: Jossey-Bass.

U.S. Bureau of Labor Statistics (2016) http://www.bls.gov/ooh/Architecture-and-Engineering/

Zaharim, A., Yusoff, Y., Omar, M. Z., Mohamed, A., \& Muhamed, N. (2009). Engineering Employability Skills Required by Employers in Asia. 6th WSEAS International Conference on Engineering Education, Stevens Point, 22-24 July 2009, 195-201. 
Appendix 1: Field Soft Skill Cluster and Characteristic Mean, Ordered by B.E. Rank

Table A1. Core skills mean, N, and standard deviation by employment field.

\begin{tabular}{|c|c|c|c|c|c|c|c|c|}
\hline & & Communication & DM/PS & Self-Mang & Experiences & Team & Prof. & Lead. \\
\hline \multirow[t]{3}{*}{ B.E. } & Mean & 3.0995 & 3.1783 & 3.641 & 4.012 & 4.2177 & 4.6501 & 5.1501 \\
\hline & $\mathrm{N}$ & 915 & 914 & 908 & 913 & 905 & 906 & 913 \\
\hline & Std Dev & 1.72571 & 1.78651 & 1.89264 & 2.25338 & 1.78679 & 1.85499 & 1.77965 \\
\hline \multirow[t]{3}{*}{ Ag. Services } & Mean & 3.017 & 3.2625 & 3.5443 & 4.3735 & 4.4009 & 4.658 & 4.6848 \\
\hline & $\mathrm{N}$ & 1354 & 1355 & 1354 & 1344 & 1352 & 1351 & 1345 \\
\hline & Std Dev & 1.6493 & 1.7864 & 1.90573 & 2.28865 & 1.78544 & 1.87419 & 1.89186 \\
\hline \multirow[t]{3}{*}{ Education } & Mean & 3.0395 & 3.5008 & 3.7708 & 4.0695 & 4.258 & 4.5764 & 4.7643 \\
\hline & $\mathrm{N}$ & 1316 & 1324 & 1313 & 1310 & 1318 & 1322 & 1315 \\
\hline & Std Dev & 1.64581 & 1.90536 & 1.93806 & 2.2716 & 1.80321 & 1.90874 & 1.91663 \\
\hline \multirow[t]{3}{*}{$\begin{array}{l}\text { Product } \\
\text { Creation }\end{array}$} & Mean & 2.9517 & 3.5688 & 3.5933 & 4.2846 & 4.218 & 4.5526 & 4.7917 \\
\hline & $\mathrm{N}$ & 269 & 269 & 268 & 267 & 266 & 266 & 264 \\
\hline & Std Dev & 1.66434 & 1.78925 & 1.85895 & 2.33184 & 1.88875 & 1.91495 & 1.86985 \\
\hline \multirow[t]{3}{*}{ Gov’t } & Mean & 2.8276 & 3.4148 & 3.5725 & 4.1737 & 4.297 & 4.625 & 5.005 \\
\hline & $\mathrm{N}$ & 406 & 405 & 407 & 403 & 404 & 400 & 403 \\
\hline & Std Dev & 1.60087 & 1.8417 & 1.88042 & 2.2724 & 1.79215 & 1.7972 & 1.85144 \\
\hline \multirow[t]{3}{*}{$\begin{array}{c}\text { Health } \\
\text { Services }\end{array}$} & Mean & 2.9653 & 3.4486 & 3.9947 & 3.8612 & 4.3449 & 4.3924 & 4.9672 \\
\hline & $\mathrm{N}$ & 951 & 954 & 949 & 951 & 948 & 948 & 945 \\
\hline & Std Dev & 1.67202 & 1.841 & 1.92446 & 2.3037 & 1.80817 & 1.86278 & 1.85661 \\
\hline \multirow[t]{3}{*}{$\begin{array}{l}\text { Service } \\
\text { Industry }\end{array}$} & Mean & 2.8029 & 3.7432 & 3.77 & 4.321 & 4.4017 & 4.4432 & 4.4839 \\
\hline & $\mathrm{N}$ & 842 & 841 & 839 & 841 & 839 & 837 & 841 \\
\hline & Std Dev & 1.6354 & 1.8729 & 1.93221 & 2.27704 & 1.83497 & 1.8472 & 1.97606 \\
\hline \multirow[t]{3}{*}{ Other } & Mean & 2.9121 & 3.5258 & 3.6707 & 4.3183 & 4.1781 & 4.4436 & 4.9191 \\
\hline & $\mathrm{N}$ & 660 & 658 & 656 & 663 & 667 & 656 & 655 \\
\hline & Std Dev & 1.63465 & 1.89023 & 1.93832 & 2.30389 & 1.75225 & 1.91734 & 1.89023 \\
\hline \multirow[t]{3}{*}{ Non-B.E. } & Mean & 2.9543 & 3.4719 & 3.7209 & 4.1883 & 4.3183 & 4.5332 & 4.7738 \\
\hline & $\mathrm{N}$ & 5798 & 5806 & 5786 & 5779 & 5784 & 5780 & 5768 \\
\hline & Std Dev & 1.64731 & 1.84987 & 1.92487 & 2.29441 & 1.80288 & 1.87951 & 1.90633 \\
\hline
\end{tabular}


Table A2. Communication characteristics mean, N, and Std. Dev. by employment field.

\begin{tabular}{|c|c|c|c|c|c|c|c|c|}
\hline \multicolumn{2}{|c|}{ Communication } & \multirow{2}{*}{$\begin{array}{l}\text { Char.1 } \\
2.9035\end{array}$} & \multirow{2}{*}{$\begin{array}{l}\text { Char.2 } \\
2.9385\end{array}$} & \multirow{2}{*}{$\begin{array}{c}\text { Char.3 } \\
3.401\end{array}$} & \multirow{2}{*}{$\begin{array}{l}\text { Char.4 } \\
3.7873\end{array}$} & \multirow{2}{*}{$\begin{array}{l}\text { Char.5 } \\
3.8869\end{array}$} & \multirow{2}{*}{$\begin{array}{l}\text { Char.6 } \\
4.7667\end{array}$} & \multirow{2}{*}{$\begin{array}{l}\text { Char.7 } \\
6.2149\end{array}$} \\
\hline B.E. & Mean & & & & & & & \\
\hline & $\mathrm{N}$ & 964 & 960 & 965 & 964 & 964 & 960 & 968 \\
\hline & Std Dev & 1.62408 & 1.67462 & 1.63716 & 1.85771 & 1.72052 & 1.76802 & 1.46214 \\
\hline \multirow[t]{3}{*}{ Ag. Services } & Mean & 2.8928 & 2.8737 & 3.3004 & 3.7405 & 4.1314 & 4.5935 & 6.3395 \\
\hline & $\mathrm{N}$ & 1409 & 1401 & 1405 & 1391 & 1393 & 1395 & 1405 \\
\hline & Std Dev & 1.66618 & 1.63153 & 1.59443 & 1.81546 & 1.73266 & 1.75193 & 1.30391 \\
\hline \multirow[t]{3}{*}{ Education } & Mean & 3.0975 & 2.9492 & 3.2479 & 3.6739 & 3.8968 & 4.9913 & 6.0845 \\
\hline & $\mathrm{N}$ & 1395 & 1399 & 1400 & 1389 & 1396 & 1386 & 1396 \\
\hline & Std Dev & 1.69622 & 1.70193 & 1.63175 & 1.88526 & 1.6787 & 1.72346 & 1.50365 \\
\hline \multirow{3}{*}{$\begin{array}{l}\text { Product } \\
\text { Creation }\end{array}$} & Mean & 2.9618 & 2.8188 & 3.4216 & 3.4181 & 4.3611 & 4.7359 & 6.2359 \\
\hline & $\mathrm{N}$ & 288 & 287 & 287 & 287 & 288 & 284 & 284 \\
\hline & Std Dev & 1.62363 & 1.66471 & 1.63868 & 1.88463 & 1.68664 & 1.80419 & 1.26825 \\
\hline \multirow[t]{3}{*}{ Government } & Mean & 3.1061 & 2.9387 & 3.2653 & 3.7911 & 3.5482 & 4.9929 & 6.283 \\
\hline & $\mathrm{N}$ & 424 & 424 & 426 & 426 & 425 & 420 & 424 \\
\hline & Std Dev & 1.71092 & 1.66908 & 1.55905 & 1.84353 & 1.69854 & 1.67744 & 1.35273 \\
\hline \multirow[t]{3}{*}{$\begin{array}{l}\text { Health } \\
\text { Services }\end{array}$} & Mean & 3.1124 & 2.8659 & 3.254 & 3.2794 & 4.2396 & 5.042 & 6.1157 \\
\hline & $\mathrm{N}$ & 1014 & 1007 & 1012 & 1002 & 1006 & 1001 & 1003 \\
\hline & Std Dev & 1.65636 & 1.66859 & 1.61709 & 1.84887 & 1.64189 & 1.68233 & 1.46025 \\
\hline \multirow[t]{3}{*}{$\begin{array}{l}\text { Service } \\
\text { Industry }\end{array}$} & Mean & 3.0478 & 3.143 & 3.3396 & 3.4166 & 4.0988 & 4.9978 & 5.8266 \\
\hline & $\mathrm{N}$ & 900 & 902 & 898 & 905 & 1006 & 897 & 894 \\
\hline & Std Dev & 1.68053 & 1.71581 & 1.66122 & 1.92272 & 1.64189 & 1.7684 & 1.68921 \\
\hline \multirow[t]{3}{*}{ Other } & Mean & 2.962 & 3.0564 & 3.3975 & 3.6051 & 3.8956 & 4.8842 & 6.1231 \\
\hline & $\mathrm{N}$ & 711 & 709 & 712 & 709 & 709 & 708 & 707 \\
\hline & Std Dev & 1.65128 & 1.75463 & 1.64352 & 1.93592 & 1.6563 & 1.76742 & 1.44703 \\
\hline \multirow[t]{3}{*}{ Non-B.E. } & Mean & 3.0243 & 2.9524 & 3.301 & 3.5744 & 4.0337 & 4.8852 & 6.1358 \\
\hline & $\mathrm{N}$ & 6141 & 6129 & 6140 & 6109 & 6108 & 6091 & 6113 \\
\hline & Std Dev & 1.67446 & 1.6871 & 1.62214 & 1.87971 & 1.70451 & 1.74362 & 1.46364 \\
\hline
\end{tabular}

1) Listen effectively; 2) Communicate accurately and concisely; 3) Effective oral communications; 4) Communicate pleasantly and professionally; 5) Effective written communications; 6) Ask good questions; 7) Communicate appropriately and professionally using social media. 
Table A3. DM/PS characteristics mean, N, and Std. Dev. by employment field.

\begin{tabular}{|c|c|c|c|c|c|c|c|c|}
\hline \multicolumn{2}{|c|}{ DMPS } & \multirow{2}{*}{$\begin{array}{l}\text { Char.1 } \\
2.445\end{array}$} & \multirow{2}{*}{$\begin{array}{c}\text { Char.2 } \\
3.485\end{array}$} & \multirow{2}{*}{$\begin{array}{l}\text { Char.3 } \\
3.884\end{array}$} & \multirow{2}{*}{$\begin{array}{l}\text { Char.4 } \\
3.9151\end{array}$} & \multirow{2}{*}{$\begin{array}{l}\text { Char.5 } \\
4.0129\end{array}$} & \multirow{2}{*}{$\begin{array}{l}\text { Char.6 } \\
5.0699\end{array}$} & \multirow{2}{*}{$\begin{array}{l}\text { Char.7 } \\
5.1182\end{array}$} \\
\hline B.E. & Mean & & & & & & & \\
\hline & $\mathrm{N}$ & 928 & 932 & 932 & 930 & 927 & 930 & 931 \\
\hline & Std Dev & 1.59665 & 1.77729 & 1.76747 & 1.69095 & 1.74876 & 2.15604 & 1.86898 \\
\hline \multirow[t]{3}{*}{ Ag. Services } & Mean & 2.372 & 3.3617 & 3.9583 & 3.8206 & 3.9853 & 4.972 & 5.4411 \\
\hline & $\mathrm{N}$ & 1363 & 1363 & 1368 & 1366 & 1359 & 1259 & 1358 \\
\hline & Std Dev & 1.60405 & 1.71001 & 1.75671 & 1.6586 & 1.73539 & 2.14375 & 1.7149 \\
\hline \multirow[t]{3}{*}{ Education } & Mean & 2.7204 & 3.5879 & 3.8342 & 3.8379 & 4.0787 & 4.618 & 5.2832 \\
\hline & $\mathrm{N}$ & 1341 & 1337 & 1339 & 1326 & 1334 & 1335 & 1331 \\
\hline & Std Dev & 1.71258 & 1.78984 & 1.79253 & 1.75352 & 1.77182 & 2.28304 & 1.8288 \\
\hline \multirow[t]{3}{*}{$\begin{array}{l}\text { Product } \\
\text { Creation }\end{array}$} & Mean & 2.4317 & 3.3123 & 3.8051 & 3.9333 & 4.2677 & 5.0145 & 5.2463 \\
\hline & $\mathrm{N}$ & 271 & 269 & 272 & 270 & 269 & 271 & 268 \\
\hline & Std Dev & 1.68048 & 1.63425 & 1.75499 & 1.66173 & 1.85955 & 2.16835 & 1.788817 \\
\hline \multirow[t]{3}{*}{ Government } & Mean & 2.2767 & 3.3123 & 3.7791 & 3.7341 & 4.3154 & 5.0145 & 5.4927 \\
\hline & $\mathrm{N}$ & 412 & 413 & 412 & 410 & 409 & 414 & 412 \\
\hline & Std Dev & 1.48345 & 1.71707 & 1.76537 & 1.60685 & 1.71521 & 2.09918 & 1.69942 \\
\hline \multirow[t]{3}{*}{$\begin{array}{l}\text { Health } \\
\text { Services }\end{array}$} & Mean & 2.5745 & 3.2544 & 3.889 & 3.8416 & 4.2724 & 4.7127 & 5.4035 \\
\hline & $\mathrm{N}$ & 973 & 967 & 973 & 972 & 969 & 971 & 969 \\
\hline & Std Dev & 1.65858 & 1.69868 & 1.76792 & 1.7429 & 1.78841 & 2.21914 & 1.69809 \\
\hline \multirow[t]{3}{*}{$\begin{array}{l}\text { Service } \\
\text { Industry }\end{array}$} & Mean & 2.6332 & 3.4725 & 3.945 & 3.7934 & 4.1074 & 4.6643 & 5.3117 \\
\hline & $\mathrm{N}$ & 856 & 853 & 855 & 852 & 857 & 858 & 847 \\
\hline & Std Dev & 1.71024 & 1.76381 & 1.83143 & 1.71248 & 1.83302 & 2.23511 & 1.7155 \\
\hline \multirow[t]{3}{*}{ Other } & Mean & 2.6141 & 3.4653 & 3.8041 & 3.6313 & 4.0605 & 5.0266 & 5.3333 \\
\hline & $\mathrm{N}$ & 679 & 677 & 679 & 678 & 678 & 676 & 678 \\
\hline & Std Dev & 1.68933 & 1.69424 & 1.84701 & 1.70922 & 1.80943 & 2.13594 & 1.7044 \\
\hline \multirow[t]{3}{*}{ Non-B.E. } & Mean & 2.5466 & 3.4178 & 3.8795 & 3.8013 & 4.1163 & 4.8125 & 5.3626 \\
\hline & $\mathrm{N}$ & 5895 & 5879 & 5898 & 5874 & 5875 & 5884 & 5863 \\
\hline & Std Dev & 1.66487 & 1.73293 & 1.78899 & 1.70541 & 1.7825 & 2.20442 & 1.74055 \\
\hline
\end{tabular}

1) Identify and analyze problems; 2) Take effective and appropriate action; 3) Transfer knowledge across situations; 4) Realize the effect of decisions; 5) Creative and have innovative solutions; 6) Engage in life-long learning; 7) Think abstractly about problems. 
Table A4. Self-management characteristics mean, N, and Std. Dev. by employment field.

\begin{tabular}{|c|c|c|c|c|c|c|c|c|}
\hline \multicolumn{2}{|c|}{ Self-Management } & \multirow{2}{*}{$\begin{array}{l}\text { Char.1 } \\
2.494\end{array}$} & \multirow{2}{*}{$\begin{array}{l}\text { Char.2 } \\
3.1831\end{array}$} & \multirow{2}{*}{$\begin{array}{l}\text { Char.3 } \\
3.4065\end{array}$} & \multirow{2}{*}{$\begin{array}{l}\text { Char.4 } \\
4.1564\end{array}$} & \multirow{2}{*}{$\begin{array}{l}\text { Char.5 } \\
4.2538\end{array}$} & \multirow{2}{*}{$\begin{array}{l}\text { Char.6 } \\
5.1449\end{array}$} & \multirow{2}{*}{$\begin{array}{l}\text { Char.7 } \\
5.3076\end{array}$} \\
\hline B.E. & Mean & & & & & & & \\
\hline & $\mathrm{N}$ & 923 & 923 & 920 & 921 & 918 & 918 & 920 \\
\hline & Std Dev & 1.54776 & 1.90503 & 1.98086 & 1.67055 & 1.77154 & 1.63779 & 1.73924 \\
\hline \multirow[t]{3}{*}{ Ag. Services } & Mean & 2.6977 & 2.7865 & 3.4123 & 4.1567 & 4.0725 & 5.3341 & 5.471 \\
\hline & $\mathrm{N}$ & 1363 & 1363 & 1363 & 1359 & 1365 & 1350 & 1361 \\
\hline & Std Dev & 1.47904 & 1.76457 & 2.01213 & 1.71874 & 1.73751 & 1.56933 & 1.64833 \\
\hline \multirow[t]{3}{*}{ Education } & Mean & 2.598 & 3.2114 & 3.463 & 4.1282 & 4.4706 & 5.1199 & 4.9902 \\
\hline & $\mathrm{N}$ & 1326 & 1329 & 1226 & 1326 & 1328 & 1318 & 1324 \\
\hline & Std Dev & 1.57402 & 1.89116 & 2.01311 & 1.75525 & 1.79021 & 1.67592 & 1.86037 \\
\hline \multirow[t]{3}{*}{$\begin{array}{l}\text { Product } \\
\text { Creation }\end{array}$} & Mean & 2.744 & 3.1365 & 3.459 & 3.9705 & 4.1194 & 5.391 & 5.1375 \\
\hline & $\mathrm{N}$ & 270 & 271 & 268 & 271 & 268 & 266 & 269 \\
\hline & Std Dev & 1.6239 & 1.81552 & 2.07766 & 1.68189 & 1.78862 & 1.64757 & 1.83652 \\
\hline \multirow[t]{3}{*}{ Government } & Mean & 2.5594 & 2.8511 & 3.5608 & 3.9728 & 4.4889 & 5.0902 & 5.3951 \\
\hline & $\mathrm{N}$ & 404 & 403 & 403 & 405 & 405 & 399 & 405 \\
\hline & Std Dev & 1.50068 & 1.77115 & 1.95042 & 1.70809 & 1.77385 & 1.67658 & 1.71683 \\
\hline \multirow{3}{*}{$\begin{array}{l}\text { Health } \\
\text { Services }\end{array}$} & Mean & 2.4943 & 3.5114 & 3.4029 & 3.8604 & 4.2845 & 5.441 & 4.9813 \\
\hline & $\mathrm{N}$ & 967 & 964 & 968 & 967 & 963 & 957 & 961 \\
\hline & Std Dev & 1.46658 & 1.96408 & 2.04774 & 1.73866 & 1.73206 & 1.56582 & 1.82622 \\
\hline \multirow[t]{3}{*}{$\begin{array}{l}\text { Service } \\
\text { Industry }\end{array}$} & Mean & 2.809 & 3.2594 & 3.2986 & 3.8538 & 4.2743 & 5.383 & 5.0552 \\
\hline & $\mathrm{N}$ & 848 & 852 & 854 & 848 & 853 & 846 & 852 \\
\hline & Std Dev & 1.57349 & 1.95594 & 1.99262 & 1.71109 & 1.75287 & 1.64907 & 1.84359 \\
\hline \multirow[t]{3}{*}{ Other } & Mean & 2.6701 & 3.2341 & 3.4218 & 3.9054 & 4.1931 & 5.3063 & 5.2096 \\
\hline & $\mathrm{N}$ & 673 & 675 & 671 & 666 & 668 & 666 & 668 \\
\hline & Std Dev & 1.55493 & 1.98399 & 1.98939 & 1.70053 & 1.7651 & 1.59488 & 1.81971 \\
\hline \multirow[t]{3}{*}{ Non-B.E. } & Mean & 2.6471 & 3.1432 & 3.4191 & 4.0072 & 4.272 & 5.2928 & 5.1702 \\
\hline & $\mathrm{N}$ & 5851 & 5857 & 5853 & 5842 & 5850 & 5802 & 5840 \\
\hline & Std Dev & 1.53234 & 1.8994 & 2.01171 & 1.72882 & 1.76468 & 1.62305 & 1.79939 \\
\hline
\end{tabular}

1) Efficient and effective work habits; 2) Self-starting; 3) Well-developed ethic, integrity and loyalty; 4) Work well under pressure; 5) Sense of urgency to complete tasks; 6) Adapt and apply appropriate technology; 7) Dedication to continued professional development. 
Table A5. Experience characteristics mean, N, and Std. Dev. by employment field.

\begin{tabular}{|c|c|c|c|c|c|c|c|c|}
\hline \multicolumn{2}{|c|}{ Experiences } & \multirow{2}{*}{$\begin{array}{l}\text { Char.1 } \\
2.6579\end{array}$} & \multirow{2}{*}{$\begin{array}{l}\text { Char.2 } \\
3.1848\end{array}$} & \multirow{2}{*}{$\begin{array}{l}\text { Char.3 } \\
3.2212\end{array}$} & \multirow{2}{*}{$\begin{array}{c}\text { Char.4 } \\
3.569\end{array}$} & \multirow{2}{*}{$\begin{array}{l}\text { Char.5 } \\
3.9151\end{array}$} & \multirow{2}{*}{$\begin{array}{c}\text { Char.6 } \\
4.954\end{array}$} & \multirow{2}{*}{$\begin{array}{l}\text { Char.7 } \\
6.2158\end{array}$} \\
\hline B.E. & Mean & & & & & & & \\
\hline & $\mathrm{N}$ & 994 & 990 & 990 & 993 & 989 & 1000 & 1001 \\
\hline & Std Dev & 1.62176 & 1.82089 & 1.54034 & 1.79872 & 1.66922 & 1.55122 & 1.37164 \\
\hline \multirow[t]{3}{*}{ Ag. Services } & Mean & 2.508 & 4.0677 & 2.9971 & 3.0349 & 3.6065 & 5.3107 & 6.2421 \\
\hline & $\mathrm{N}$ & 1429 & 1414 & 1401 & 1405 & 1413 & 1413 & 1433 \\
\hline & Std Dev & 1.65454 & 1.7135 & 1.52268 & 1.58593 & 1.61026 & 1.41437 & 1.26871 \\
\hline \multirow[t]{3}{*}{ Education } & Mean & 2.6137 & 3.3921 & 3.1259 & 3.6815 & 3.9915 & 4.7836 & 6.2507 \\
\hline & $\mathrm{N}$ & 1411 & 1418 & 1422 & 1413 & 1417 & 1405 & 1428 \\
\hline & Std Dev & 1.63527 & 1.90901 & 1.55193 & 1.84581 & 1.62821 & 1.62078 & 1.26963 \\
\hline \multirow[t]{3}{*}{$\begin{array}{l}\text { Product } \\
\text { Creation }\end{array}$} & Mean & 2.7166 & 3.1623 & 3.0984 & 3.8284 & 3.604 & 5.1461 & 6.3062 \\
\hline & $\mathrm{N}$ & 307 & 302 & 305 & 303 & 303 & 308 & 307 \\
\hline & Std Dev & 1.61523 & 1.85437 & 1.46567 & 1.899 & 1.54885 & 1.45332 & 1.29 \\
\hline \multirow[t]{3}{*}{ Government } & Mean & 2.4507 & 3.7725 & 3.2734 & 2.9953 & 3.9548 & 5.0024 & 6.3505 \\
\hline & $\mathrm{N}$ & 426 & 422 & 428 & 427 & 420 & 424 & 428 \\
\hline & Std Dev & 1.59076 & 1.74242 & 1.58078 & 1.55795 & 1.61596 & 1.54598 & 1.3088 \\
\hline \multirow{3}{*}{$\begin{array}{l}\text { Health } \\
\text { Services }\end{array}$} & Mean & 2.3977 & 3.3798 & 3.1779 & 3.5855 & 4.0252 & 4.9432 & 6.2557 \\
\hline & $\mathrm{N}$ & 1041 & 1032 & 1037 & 1035 & 1031 & 1039 & 1056 \\
\hline & Std Dev & 1.50236 & 1.90947 & 1.4958 & 1.80027 & 1.55274 & 1.59589 & 1.29269 \\
\hline \multirow[t]{3}{*}{$\begin{array}{l}\text { Service } \\
\text { Industry }\end{array}$} & Mean & 2.4774 & 3.4036 & 3.0139 & 3.9465 & 3.7769 & 4.9082 & 6.1623 \\
\hline & $\mathrm{N}$ & 930 & 939 & 938 & 935 & 928 & 926 & 955 \\
\hline & Std Dev & 1.55904 & 1.90612 & 1.4722 & 1.89424 & 1.55476 & 1.57864 & 1.37431 \\
\hline \multirow[t]{3}{*}{ Other } & Mean & 2.7186 & 3.5014 & 3.1407 & 3.4765 & 3.9906 & 4.9604 & 6.0241 \\
\hline & $\mathrm{N}$ & 725 & 736 & 739 & 745 & 747 & 732 & 746 \\
\hline & Std Dev & 1.65648 & 1.92018 & 1.5958 & 1.9 & 1.62625 & 1.57696 & 1.51395 \\
\hline \multirow{3}{*}{ Non-B.E. } & Mean & 2.5396 & 3.572 & 3.0994 & 3.4961 & 3.857 & 5.0013 & 6.2191 \\
\hline & $\mathrm{N}$ & 6269 & 6266 & 6267 & 6233 & 6259 & 6247 & 6353 \\
\hline & Std Dev & 1.60842 & 1.87571 & 1.52922 & 1.81109 & 1.60481 & 1.55793 & 1.32567 \\
\hline
\end{tabular}

1) Related work or internship experiences; 2) Cross disciplinary experiences; 3) Leadership experiences; 4) Teamwork experiences; 5) Project management experiences; 6) Community engagement experiences; 7) International experiences. 
Table A6. Teamwork characteristics mean, N, and Std. Dev. by employment field.

\begin{tabular}{|c|c|c|c|c|c|c|c|c|}
\hline \multicolumn{2}{|c|}{ Team Skills } & \multirow{2}{*}{$\begin{array}{l}\text { Char.1 } \\
2.5493\end{array}$} & \multirow{2}{*}{$\begin{array}{l}\text { Char.2 } \\
2.8854\end{array}$} & \multirow{2}{*}{$\begin{array}{l}\text { Char.3 } \\
3.2078\end{array}$} & \multirow{2}{*}{$\begin{array}{l}\text { Char.4 } \\
3.5071\end{array}$} & \multirow{2}{*}{$\begin{array}{l}\text { Char.5 } \\
4.4033\end{array}$} & \multirow{2}{*}{$\begin{array}{l}\text { Char.6 } \\
5.5649\end{array}$} & \multirow{2}{*}{$\begin{array}{l}\text { Char.7 } \\
5.7222\end{array}$} \\
\hline B.E. & Mean & & & & & & & \\
\hline & $\mathrm{N}$ & 974 & 977 & 972 & 984 & 967 & 979 & 979 \\
\hline & Std Dev & 1.56567 & 1.54149 & 1.77696 & 1.57354 & 1.74477 & 1.44236 & 1.59512 \\
\hline \multirow[t]{3}{*}{ Ag. Services } & Mean & 2.5825 & 2.9822 & 2.9786 & 3.5029 & 4.4527 & 5.4668 & 5.8777 \\
\hline & $\mathrm{N}$ & 1406 & 1405 & 1400 & 1396 & 1405 & 1401 & 1390 \\
\hline & Std Dev & 1.51668 & 1.53695 & 1.76483 & 1.59412 & 1.71513 & 1.51486 & 1.45318 \\
\hline \multirow[t]{3}{*}{ Education } & Mean & 2.6205 & 3.0763 & 3.1757 & 3.7546 & 4.446 & 5.3976 & 5.445 \\
\hline & $\mathrm{N}$ & 1402 & 1403 & 1406 & 1398 & 1388 & 1396 & 1409 \\
\hline & Std Dev & 1.60213 & 1.7281 & 1.78798 & 1.68425 & 1.79981 & 1.62162 & 1.68043 \\
\hline \multirow[t]{3}{*}{$\begin{array}{l}\text { Product } \\
\text { Creation }\end{array}$} & Mean & 2.5597 & 2.8562 & 3.1414 & 3.4932 & 4.5068 & 5.4146 & 5.9313 \\
\hline & $\mathrm{N}$ & 293 & 292 & 290 & 292 & 292 & 287 & 291 \\
\hline & Std Dev & 1.53074 & 1.62451 & 1.73026 & 1.60432 & 1.64451 & 1.46719 & 1.50473 \\
\hline \multirow[t]{3}{*}{ Government } & Mean & 2.5644 & 2.9605 & 3.2813 & 3.5647 & 4.3664 & 5.4182 & 5.7048 \\
\hline & $\mathrm{N}$ & 427 & 430 & 423 & 425 & 423 & 428 & 420 \\
\hline & Std Dev & 1.54812 & 1.67132 & 1.80016 & 1.67422 & 1.78076 & 1.49326 & 1.52887 \\
\hline \multirow[t]{3}{*}{$\begin{array}{l}\text { Health } \\
\text { Services }\end{array}$} & Mean & 2.5987 & 2.8656 & 3.0174 & 3.5693 & 4.5794 & 5.6523 & 5.5792 \\
\hline & $\mathrm{N}$ & 1028 & 1027 & 1033 & 1024 & 1027 & 1024 & 1027 \\
\hline & Std Dev & 1.50594 & 1.59172 & 1.72017 & 1.63571 & 1.69113 & 1.44371 & 1.61004 \\
\hline \multirow[t]{3}{*}{$\begin{array}{l}\text { Service } \\
\text { Industry }\end{array}$} & Mean & 2.7188 & 2.8593 & 3.051 & 3.5121 & 4.5741 & 5.4007 & 5.6692 \\
\hline & $\mathrm{N}$ & 914 & 910 & 916 & 908 & 904 & 906 & 916 \\
\hline & Std Dev & 1.55538 & 1.58929 & 1.70452 & 1.65852 & 1.75871 & 1.53902 & 1.61508 \\
\hline \multirow[t]{3}{*}{ Other } & Mean & 2.6074 & 3.0109 & 3.2058 & 3.5873 & 4.4814 & 5.4827 & 5.4691 \\
\hline & $\mathrm{N}$ & 726 & 734 & 729 & 727 & 725 & 721 & 729 \\
\hline & Std Dev & 1.60307 & 1.67638 & 1.76549 & 1.66234 & 1.79664 & 1.49724 & 1.71193 \\
\hline \multirow[t]{3}{*}{ Non-B.E. } & Mean & 2.6144 & 2.9621 & 3.0917 & 3.5861 & 4.4901 & 5.4683 & 5.6412 \\
\hline & $\mathrm{N}$ & 6196 & 6201 & 6197 & 6170 & 6164 & 6163 & 6184 \\
\hline & Std Dev & 1.55335 & 1.62977 & 1.75693 & 1.64733 & 1.74834 & 1.52798 & 1.60435 \\
\hline
\end{tabular}

1) Productive as a team member; 2) Punctual and meets deadlines; 3) Positive and encouraging attitude; 4) Maintains accountability to the team; 5) Work with multiple approaches; 6) Share ideas to multiple audiences; 7) Aware and sensitive to diversity. 
Table A7. Professionalism characteristics mean, N, and Std. Dev. by employment field.

\begin{tabular}{|c|c|c|c|c|c|c|c|c|}
\hline \multicolumn{2}{|c|}{ Professionalism } & \multirow{2}{*}{$\begin{array}{l}\text { Char.1 } \\
2.8729\end{array}$} & \multirow{2}{*}{$\begin{array}{l}\text { Char.2 } \\
3.4189\end{array}$} & \multirow{2}{*}{$\begin{array}{l}\text { Char.3 } \\
3.4961\end{array}$} & \multirow{2}{*}{$\begin{array}{l}\text { Char.4 } \\
3.7858\end{array}$} & \multirow{2}{*}{$\begin{array}{l}\text { Char.5 } \\
4.7269\end{array}$} & \multirow{2}{*}{$\begin{array}{c}\text { Char.6 } \\
4.73\end{array}$} & \multirow{2}{*}{$\begin{array}{l}\text { Char.7 } \\
4.9062\end{array}$} \\
\hline B.E. & Mean & & & & & & & \\
\hline & $\mathrm{N}$ & 913 & 912 & 909 & 915 & 908 & 911 & 906 \\
\hline & Std Dev & 1.8482 & 1.77987 & 1.86116 & 1.99343 & 1.86012 & 1.85488 & 1.81675 \\
\hline \multirow[t]{3}{*}{ Ag. Services } & Mean & 2.848 & 3.5529 & 3.3023 & 3.7626 & 4.6957 & 4.7575 & 5.0614 \\
\hline & $\mathrm{N}$ & 1349 & 1351 & 1343 & 1348 & 1334 & 1336 & 1335 \\
\hline & Std Dev & 1.83031 & 1.72647 & 1.78236 & 2.00594 & 1.85329 & 1.8654 & 1.81386 \\
\hline \multirow[t]{3}{*}{ Education } & Mean & 3.0853 & 3.421 & 3.1971 & 3.8279 & 4.7701 & 4.6245 & 5.0404 \\
\hline & $\mathrm{N}$ & 1325 & 1323 & 1319 & 1325 & 1318 & 1321 & 1312 \\
\hline & Std Dev & 1.90748 & 1.7504 & 1.83515 & 2.01594 & 1.80679 & 1.87685 & 1.79474 \\
\hline \multirow[t]{3}{*}{$\begin{array}{l}\text { Product } \\
\text { Creation }\end{array}$} & Mean & 2.6779 & 3.6466 & 3.4906 & 3.6805 & 4.597 & 5.0152 & 4.8083 \\
\hline & $\mathrm{N}$ & 267 & 266 & 267 & 266 & 263 & 264 & 266 \\
\hline & Std Dev & 1.71712 & 1.82103 & 1.85846 & 1.90515 & 1.94119 & 1.83744 & 1.83388 \\
\hline \multirow[t]{3}{*}{ Government } & Mean & 2.625 & 3.4791 & 3.2759 & 3.9581 & 4.656 & 5.1358 & 4.837 \\
\hline & $\mathrm{N}$ & 408 & 407 & 406 & 406 & 407 & 405 & 405 \\
\hline & Std Dev & 1.76898 & 1.7074 & 1.77854 & 2.00141 & 1.80438 & 1.77268 & 1.73155 \\
\hline \multirow{3}{*}{$\begin{array}{l}\text { Health } \\
\text { Services }\end{array}$} & Mean & 2.8046 & 3.524 & 3.2247 & 3.6855 & 4.5735 & 4.8847 & 5.2696 \\
\hline & $\mathrm{N}$ & 957 & 960 & 957 & 957 & 952 & 9554 & 946 \\
\hline & Std Dev & 1.73942 & 1.76084 & 1.76457 & 1.98749 & 1.89716 & 1.79112 & 1.71648 \\
\hline \multirow[t]{3}{*}{$\begin{array}{l}\text { Service } \\
\text { Industry }\end{array}$} & Mean & 2.4503 & 3.7497 & 3.0383 & 3.9555 & 4.7665 & 4.9006 & 5.0734 \\
\hline & $\mathrm{N}$ & 835 & 835 & 835 & 831 & 831 & 835 & 831 \\
\hline & Std Dev & 1.58934 & 1.76588 & 1.7693 & 1.94854 & 1.77761 & 1.77538 & 1.78228 \\
\hline \multirow[t]{3}{*}{ Other } & Mean & 2.7534 & 3.4909 & 3.4333 & 3.634 & 4.7961 & 4.9105 & 4.8826 \\
\hline & $\mathrm{N}$ & 661 & 658 & 660 & 664 & 662 & 659 & 656 \\
\hline & Std Dev & 1.76875 & 1.71236 & 1.84944 & 1.95734 & 1.84312 & 1.79399 & 1.89171 \\
\hline \multirow[t]{3}{*}{ Non-B.E. } & Mean & 2.8035 & 3.5384 & 3.2492 & 3.7876 & 4.707 & 4.8246 & 5.0447 \\
\hline & $\mathrm{N}$ & 5802 & 5800 & 5787 & 5797 & 5767 & 5774 & 5751 \\
\hline & Std Dev & 1.79476 & 1.74704 & 1.80384 & 1.98856 & 1.83959 & 1.83208 & 1.80442 \\
\hline
\end{tabular}

1) Effective relationships with customers, businesses and the public; 2) Accept critique and direction in the work place; 3) Trustworthy with sensitive information; 4) Understand role, realistic career expectations; 5) Maintain appropriate decor and demeanor; 6) Select mentor and acceptance of advice; 7) Deal effectively with ambiguity. 
Table A8. Leadership characteristics mean, N, and Std. Dev. by employment field.

\begin{tabular}{|c|c|c|c|c|c|c|c|c|}
\hline \multicolumn{2}{|c|}{ Leadership } & \multirow{2}{*}{$\begin{array}{l}\text { Char.1 } \\
3.1086\end{array}$} & \multirow{2}{*}{$\begin{array}{l}\text { Char.2 } \\
3.3614\end{array}$} & \multirow{2}{*}{$\begin{array}{l}\text { Char.3 } \\
3.7838\end{array}$} & \multirow{2}{*}{$\begin{array}{l}\text { Char.4 } \\
3.8658\end{array}$} & \multirow{2}{*}{$\begin{array}{l}\text { Char.5 } \\
4.2905\end{array}$} & \multirow{2}{*}{$\begin{array}{l}\text { Char.6 } \\
4.3344\end{array}$} & \multirow{2}{*}{$\begin{array}{l}\text { Char.7 } \\
5.1994\end{array}$} \\
\hline B.E. & Mean & & & & & & & \\
\hline & $\mathrm{N}$ & 948 & 949 & 948 & 946 & 933 & 948 & 943 \\
\hline & Std Dev & 1.98936 & 1.93759 & 1.70862 & 1.8065 & 1.89598 & 2.09212 & 1.79954 \\
\hline \multirow[t]{3}{*}{ Ag. Services } & Mean & 3.1139 & 3.4928 & 3.8953 & 3.9435 & 4.2745 & 4.1582 & 5.0138 \\
\hline & $\mathrm{N}$ & 1378 & 1380 & 1376 & 1380 & 1366 & 1372 & 1374 \\
\hline & Std Dev & 2.0465 & 2.00704 & 1.72825 & 1.74801 & 1.92117 & 2.0465 & 1.81856 \\
\hline \multirow[t]{3}{*}{ Education } & Mean & 3.3473 & 3.351 & 3.8635 & 3.8271 & 4.3066 & 4.2504 & 4.9956 \\
\hline & $\mathrm{N}$ & 1359 & 1362 & 1355 & 1359 & 1360 & 1358 & 1356 \\
\hline & Std Dev & 2.01834 & 1.99857 & 1.73029 & 1.78407 & 1.96495 & 2.0554 & 1.90241 \\
\hline \multirow[t]{3}{*}{$\begin{array}{l}\text { Product } \\
\text { Creation }\end{array}$} & Mean & 3.2518 & 3.4255 & 3.7138 & 4.0328 & 4.5855 & 4.0978 & 4.8255 \\
\hline & $N$ & 274 & 275 & 276 & 274 & 275 & 276 & 275 \\
\hline & Std Dev & 2.05209 & 2.01021 & 1.66284 & 1.82042 & 1.89962 & 2.13742 & 1.91004 \\
\hline \multirow[t]{3}{*}{ Government } & Mean & 3.2933 & 3.2356 & 3.5721 & 3.8138 & 4.5928 & 4.0641 & 5.2909 \\
\hline & $\mathrm{N}$ & 416 & 416 & 416 & 419 & 415 & 421 & 416 \\
\hline & Std Dev & 1.97101 & 2.00175 & 1.71024 & 1.76725 & 1.89085 & 2.06171 & 1.68609 \\
\hline \multirow[t]{3}{*}{$\begin{array}{l}\text { Health } \\
\text { Services }\end{array}$} & Mean & 3.2139 & 3.3695 & 3.7366 & 3.8051 & 4.5178 & 4.3074 & 5.0061 \\
\hline & $\mathrm{N}$ & 996 & 996 & 987 & 990 & 985 & 989 & 984 \\
\hline & Std Dev & 2.02086 & 1.95786 & 1.75113 & 1.73216 & 1.9249 & 2.09794 & 1.84605 \\
\hline \multirow[t]{3}{*}{$\begin{array}{l}\text { Service } \\
\text { Industry }\end{array}$} & Mean & 3.307 & 3.44 & 3.8655 & 4.1714 & 4.3007 & 3.8446 & 4.9749 \\
\hline & $\mathrm{N}$ & 873 & 875 & 877 & 875 & 878 & 875 & 876 \\
\hline & Std Dev & 2.03854 & 1.99129 & 1.69747 & 1.83105 & 1.98243 & 2.12344 & 1.82974 \\
\hline \multirow[t]{3}{*}{ Other } & Mean & 3.3432 & 3.2925 & 3.7587 & 3.8547 & 4.3406 & 4.2511 & 5.0538 \\
\hline & $\mathrm{N}$ & 694 & 694 & 692 & 688 & 690 & 689 & 688 \\
\hline & Std Dev & 1.99145 & 2.01639 & 1.67587 & 1.81674 & 1.95485 & 2.10397 & 1.84596 \\
\hline \multirow[t]{3}{*}{ Non-B.E. } & Mean & 3.2604 & 3.3883 & 3.8108 & 3.9123 & 4.3699 & 4.1592 & 5.0179 \\
\hline & $\mathrm{N}$ & 5990 & 5998 & 5979 & 5985 & 5969 & 5980 & 5969 \\
\hline & Std Dev & 2.02463 & 1.99611 & 1.7194 & 1.78203 & 1.94414 & 2.09861 & 1.84381 \\
\hline
\end{tabular}

1) See the "big picture" and think strategically; 2) Recognize when to lead and when to follow; 3) Recognize and deal constructively with conflict; 4) Respect and acknowledge others contributions; 5) Motivate and lead others; 6) Build professional relationships; 7) Recognize change is needed and lead the change effort. 


\section{Appendix 2: Significant Differences as Compared to B.E. Field}

Table A9. Core skills significant differences by employment field.

\begin{tabular}{|c|c|c|c|c|c|c|c|c|}
\hline \multicolumn{2}{|c|}{ Skill Cluster } & \multirow{2}{*}{$\begin{array}{c}\text { Comm. } \\
0.379\end{array}$} & \multirow{2}{*}{$\begin{array}{c}\text { DMPS } \\
0.252\end{array}$} & \multirow{2}{*}{$\begin{array}{c}\text { Self-Mng } \\
0.225\end{array}$} & \multirow{2}{*}{$\begin{array}{c}\text { Exp } \\
0.000\end{array}$} & \multirow{2}{*}{$\begin{array}{c}\text { Team Skills } \\
0.016\end{array}$} & \multirow{2}{*}{$\begin{array}{l}\text { Prof. } \\
0.858\end{array}$} & \multirow{2}{*}{$\begin{array}{r}\text { Leader } \\
0.000\end{array}$} \\
\hline Ag. Services & Sig & & & & & & & \\
\hline & Wald & 0.774 & 1.311 & 1.473 & 14.575 & 5.802 & 0.032 & 33.389 \\
\hline & Std Err & 0.075 & 0.075 & 0.075 & 0.076 & 0.075 & 0.075 & 0.076 \\
\hline \multirow[t]{3}{*}{ Education } & Sig & 0.599 & 0.000 & 0.127 & 0.526 & 0.607 & 0.440 & 0.000 \\
\hline & Wald & 0.277 & 15.001 & 2.330 & 0.401 & 0.264 & 0.596 & 21.401 \\
\hline & Std Err & 0.076 & 0.076 & 0.076 & 0.076 & 0.076 & 0.076 & 0.076 \\
\hline \multirow[t]{3}{*}{$\begin{array}{l}\text { Product } \\
\text { Creation }\end{array}$} & Sig & 0.220 & 0.002 & 0.764 & 0.057 & 0.901 & 0.507 & 0.006 \\
\hline & Wald & 1.504 & 9.774 & 0.090 & 3.609 & 0.016 & 0.440 & 7.607 \\
\hline & Std Err & 0.105 & 0.122 & 0.122 & 0.122 & 0.122 & 0.122 & 0.123 \\
\hline \multirow[t]{3}{*}{ Government } & Sig & 0.011 & 0.035 & 0.570 & 0.210 & 0.406 & 0.700 & 0.226 \\
\hline & Wald & 6.492 & 4.436 & 0.322 & 1.568 & 0.690 & 0.149 & 1.468 \\
\hline & Std Err & 0.105 & 0.105 & 0.105 & 0.105 & 0.105 & 0.105 & 0.106 \\
\hline \multirow[t]{3}{*}{$\begin{array}{l}\text { Health } \\
\text { Services }\end{array}$} & Sig & 0.099 & 0.002 & 0.000 & 0.232 & 0.129 & 0.003 & 0.042 \\
\hline & Wald & 2.718 & 9.917 & 15.517 & 1.426 & 2.309 & 8.822 & 4.143 \\
\hline & Std Err & 0.082 & 0.081 & 0.081 & 0.082 & 0.081 & 0.082 & 0.082 \\
\hline \multirow[t]{3}{*}{$\begin{array}{l}\text { Service } \\
\text { Industry }\end{array}$} & Sig & 0.000 & 0.000 & 0.175 & 0.003 & 0.027 & 0.017 & 0.000 \\
\hline & Wald & 13.980 & 40.629 & 1.842 & 8.758 & 4.913 & 5.673 & 51.951 \\
\hline & Std Err & 0.084 & 0.084 & 0.084 & 0.084 & 0.084 & 0.084 & 0.084 \\
\hline \multirow[t]{3}{*}{ Other } & Sig & 0.044 & 0.000 & 0.800 & 0.006 & 0.667 & 0.037 & 0.022 \\
\hline & Wald & 4.055 & 13.778 & 0.064 & 7.585 & 0.185 & 4.349 & 5.234 \\
\hline & Std Err & 0.090 & 0.090 & 0.090 & 0.090 & 0.090 & 0.090 & 0.091 \\
\hline
\end{tabular}


Table A10. Communication characteristic significant differences.

\begin{tabular}{|c|c|c|c|c|c|c|c|c|}
\hline \multicolumn{2}{|c|}{ Communication } & \multirow{2}{*}{$\begin{array}{c}\text { Char.1 } \\
0.708\end{array}$} & \multirow{2}{*}{$\begin{array}{c}\text { Char.2 } \\
0.423\end{array}$} & \multirow{2}{*}{$\begin{array}{c}\text { Char.3 } \\
0.153\end{array}$} & \multirow{2}{*}{$\begin{array}{c}\text { Char.4 } \\
0.543\end{array}$} & \multirow{2}{*}{$\begin{array}{l}\text { Char.5 } \\
0.000\end{array}$} & \multirow{2}{*}{$\begin{array}{c}\text { Char.6 } \\
0.011\end{array}$} & \multirow{2}{*}{$\begin{array}{c}\text { Char.7 } \\
0.092\end{array}$} \\
\hline Ag. Services & Sig & & & & & & & \\
\hline & Wald & 0.140 & 0.642 & 0.204 & 0.370 & 12.506 & 6.516 & 2.840 \\
\hline & Std Err & 0.074 & 0.074 & 0.074 & 0.073 & 0.074 & 0.074 & 0.089 \\
\hline \multirow[t]{3}{*}{ Education } & Sig & 0.009 & 0.996 & 0.021 & 0.133 & 0.924 & 0.002 & 0.004 \\
\hline & Wald & 6.854 & 0.000 & 5.287 & 2.254 & 0.009 & 9.935 & 8.515 \\
\hline & Std Err & 0.074 & 0.074 & 0.074 & 0.074 & 0.074 & 0.074 & 0.086 \\
\hline \multirow[t]{3}{*}{$\begin{array}{l}\text { Product } \\
\text { Creation }\end{array}$} & Sig & 0.578 & 0.255 & 0.961 & 0.003 & 0.000 & 0.813 & 0.274 \\
\hline & Wald & 0.310 & 1.294 & 0.002 & 8.672 & 17.204 & 0.056 & 1.195 \\
\hline & Std Err & 0.119 & 0.119 & 0.118 & 0.118 & 0.118 & 0.119 & 0.138 \\
\hline \multirow[t]{3}{*}{ Government } & Sig & 0.048 & 0.977 & 0.171 & 0.948 & 0.001 & 0.036 & 0.746 \\
\hline & Wald & 3.895 & 0.001 & 1.875 & 0.004 & 11.506 & 4.411 & 0.105 \\
\hline & Std Err & 0.103 & 0.103 & 0.102 & 0.102 & 0.102 & 0.103 & 0.123 \\
\hline \multirow[t]{3}{*}{$\begin{array}{l}\text { Health } \\
\text { Services }\end{array}$} & Sig & 0.006 & 0.307 & 0.039 & 0.000 & 0.000 & 0.001 & 0.004 \\
\hline & Wald & 7.511 & 1.044 & 4.282 & 36.482 & 20.155 & 11.369 & 8.073 \\
\hline & Std Err & 0.079 & 0.080 & 0.079 & 0.079 & 0.079 & 0.080 & 0.092 \\
\hline \multirow[t]{3}{*}{$\begin{array}{l}\text { Service } \\
\text { Industry }\end{array}$} & Sig & 0.081 & 0.010 & 0.375 & 0.000 & 0.007 & 0.001 & 0.000 \\
\hline & Wald & 3.048 & 6.585 & 0.788 & 19.456 & 7.181 & 10.547 & 38.295 \\
\hline & Std Err & 0.082 & 0.082 & 0.082 & 0.081 & 0.082 & 0.082 & 0.093 \\
\hline \multirow[t]{3}{*}{ Other } & Sig & 0.519 & 0.240 & 0.899 & 0.040 & 0.936 & 0.144 & 0.019 \\
\hline & Wald & 0.415 & 1.383 & 0.016 & 4.209 & 0.006 & 2.138 & 5.543 \\
\hline & Std Err & 0.087 & 0.087 & 0.087 & 0.087 & 0.087 & 0.087 & 0.101 \\
\hline
\end{tabular}


Table A11. DM/PS characteristic significant differences.

\begin{tabular}{|c|c|c|c|c|c|c|c|c|}
\hline \multicolumn{2}{|c|}{ DMPS } & \multirow{2}{*}{$\begin{array}{l}\text { Char.1 } \\
0.152\end{array}$} & \multirow{2}{*}{$\begin{array}{c}\text { Char.2 } \\
0.111\end{array}$} & \multirow{2}{*}{$\begin{array}{c}\text { Char.3 } \\
0.396\end{array}$} & \multirow{2}{*}{$\begin{array}{c}\text { Char.4 } \\
0.214\end{array}$} & \multirow{2}{*}{$\begin{array}{c}\text { Char.5 } \\
0.720\end{array}$} & \multirow{2}{*}{$\begin{array}{c}\text { Char.6 } \\
0.116\end{array}$} & \multirow{2}{*}{$\begin{array}{r}\text { Char.7 } \\
0.000\end{array}$} \\
\hline Ag. Services & Sig & & & & & & & \\
\hline & Wald & 2.056 & 2.536 & 0.720 & 1.542 & 0.128 & 2.468 & 16.852 \\
\hline & Std Err & 0.077 & 0.075 & 0.074 & 0.075 & 0.075 & 0.076 & 0.076 \\
\hline \multirow[t]{3}{*}{ Education } & Sig & 0.000 & 0.174 & 0.440 & 0.274 & 0.428 & 0.000 & 0.022 \\
\hline & Wald & 13.636 & 1.852 & 0.597 & 1.195 & 0.629 & 24.620 & 5.232 \\
\hline & Std Err & 0.077 & 0.075 & 0.075 & 0.075 & 0.075 & 0.076 & 0.076 \\
\hline \multirow[t]{3}{*}{$\begin{array}{l}\text { Product } \\
\text { Creation }\end{array}$} & Sig & 0.622 & 0.222 & 0.499 & 0.799 & 0.033 & 0.302 & 0.351 \\
\hline & Wald & 0.243 & 1.494 & 0.456 & 0.065 & 4.523 & 1.065 & 0.870 \\
\hline & Std Err & 0.125 & 0.122 & 0.121 & 0.121 & 0.122 & 0.123 & 0.123 \\
\hline \multirow[t]{3}{*}{ Government } & Sig & 0.119 & 0.096 & 0.308 & 0.083 & 0.005 & 0.381 & 0.001 \\
\hline & Wald & 2.436 & 2.767 & 1.038 & 3.000 & 7.975 & 0.769 & 11.912 \\
\hline & Std Err & 0.108 & 0.104 & 0.104 & 0.104 & 0.104 & 0.106 & 0.106 \\
\hline \multirow[t]{3}{*}{$\begin{array}{l}\text { Health } \\
\text { Services }\end{array}$} & Sig & 0.136 & 0.006 & 0.896 & 0.314 & 0.001 & 0.000 & 0.002 \\
\hline & Wald & 2.219 & 7.678 & 0.017 & 1.014 & 10.134 & 15.737 & 9.754 \\
\hline & Std Err & 0.082 & 0.081 & 0.080 & 0.081 & 0.081 & 0.082 & 0.082 \\
\hline \multirow[t]{3}{*}{$\begin{array}{l}\text { Service } \\
\text { Industry }\end{array}$} & Sig & 0.037 & 0.871 & 0.533 & 0.118 & 0.249 & 0.000 & 0.089 \\
\hline & Wald & 4.343 & 0.026 & 0.388 & 2.448 & 1.330 & 16.733 & 2.890 \\
\hline & Std Err & 0.085 & 0.083 & 0.083 & 0.083 & 0.083 & 0.084 & 0.084 \\
\hline \multirow[t]{3}{*}{ Other } & Sig & 0.081 & 0.955 & 0.326 & 0.001 & 0.544 & 0.588 & 0.060 \\
\hline & Wald & 3.046 & 0.003 & 0.966 & 11.119 & 0.369 & 0.293 & 3.543 \\
\hline & Std Err & 0.091 & 0.089 & 0.088 & 0.089 & 0.089 & 0.091 & 0.090 \\
\hline
\end{tabular}

significant B.E. LOWER PRIORITY than comparison field;

significant B.E. HIGHER PRIORITY than comparison field.

1) Identify and analyze problems; 2) Take effective and appropriate action; 3) Transfer knowledge across situations; 4) Realize the effect of decisions;

5) Creative and have innovative solutions; 6) Engage in life-long learning; 7) Think abstractly about problems 
Table A12. Self-management characteristic significant differences.

\begin{tabular}{|c|c|c|c|c|c|c|c|c|}
\hline \multicolumn{2}{|c|}{ Self-Management } & \multirow{2}{*}{$\begin{array}{l}\text { Char.1 } \\
0.000\end{array}$} & \multirow{2}{*}{$\begin{array}{c}\text { Char.2 } \\
0.000\end{array}$} & \multirow{2}{*}{$\begin{array}{c}\text { Char.3 } \\
0.971\end{array}$} & \multirow{2}{*}{$\begin{array}{c}\text { Char.4 } \\
0.921\end{array}$} & \multirow{2}{*}{$\begin{array}{c}\text { Char.5 } \\
0.012\end{array}$} & \multirow{2}{*}{$\begin{array}{c}\text { Char.6 } \\
0.008\end{array}$} & \multirow{2}{*}{$\begin{array}{r}\text { Char.7 } \\
0.047\end{array}$} \\
\hline Ag. Services & Sig & & & & & & & \\
\hline & Wald & 17.080 & 23.553 & 0.001 & 0.010 & 6.276 & 6.986 & 3.956 \\
\hline & Std Err & 0.076 & 0.075 & 0.075 & 0.075 & 0.075 & 0.076 & 0.076 \\
\hline \multirow[t]{3}{*}{ Education } & Sig & 0.087 & 0.694 & 0.554 & 0.808 & 0.004 & 0.882 & 0.000 \\
\hline & Wald & 2.928 & 0.154 & 0.350 & 0.059 & 8.148 & 0.022 & 15.717 \\
\hline & Std Err & 0.077 & 0.075 & 0.075 & 0.075 & 0.075 & 0.076 & 0.076 \\
\hline \multirow[t]{3}{*}{$\begin{array}{l}\text { Product } \\
\text { Creation }\end{array}$} & Sig & 0.013 & 0.892 & 0.823 & 0.161 & 0.303 & 0.010 & 0.224 \\
\hline & Wald & 6.212 & 0.018 & 0.050 & 1.968 & 1.061 & 6.692 & 1.477 \\
\hline & Std Err & 0.123 & 0.122 & 0.122 & 0.121 & 0.122 & 0.124 & 0.123 \\
\hline \multirow[t]{3}{*}{ Government } & Sig & 0.245 & 0.004 & 0.186 & 0.099 & 0.027 & 0.654 & 0.339 \\
\hline & Wald & 1.349 & 8.226 & 1.753 & 2.720 & 4.878 & 0.201 & 0.915 \\
\hline & Std Err & 0.106 & 0.106 & 0.105 & 0.105 & 0.105 & 0.106 & 0.107 \\
\hline \multirow[t]{3}{*}{$\begin{array}{l}\text { Health } \\
\text { Services }\end{array}$} & Sig & 0.552 & 0.000 & 0.811 & 0.000 & 0.833 & 0.000 & 0.000 \\
\hline & Wald & 0.354 & 13.524 & 0.057 & 12.977 & 0.045 & 17.135 & 15.887 \\
\hline & Std Err & 0.082 & 0.081 & 0.081 & 0.081 & 0.081 & 0.082 & 0.082 \\
\hline \multirow[t]{3}{*}{$\begin{array}{l}\text { Service } \\
\text { Industry }\end{array}$} & Sig & 0.000 & 0.504 & 0.210 & 0.000 & 0.820 & 0.000 & 0.004 \\
\hline & Wald & 23.356 & 0.446 & 1.569 & 13.028 & 0.052 & 13.436 & 8.323 \\
\hline & Std Err & 0.085 & 0.084 & 0.084 & 0.084 & 0.083 & 0.085 & 0.084 \\
\hline \multirow[t]{3}{*}{ Other } & Sig & 0.008 & 0.818 & 0.915 & 0.006 & 0.468 & 0.047 & 0.401 \\
\hline & Wald & 7.119 & 0.053 & 0.011 & 7.520 & 0.527 & 3.929 & 0.705 \\
\hline & Std Err & 0.090 & 0.089 & 0.089 & 0.089 & 0.089 & 0.090 & 0.090 \\
\hline
\end{tabular}

significant B.E. LOWER PRIORITY than comparison field;

significant B.E. HIGHER PRIORITY than comparison field. 1) Efficient and effective work habits; 2) Self-starting; 3) Well-developed ethic, integrity and loyalty; 4) Work well under pressure; 5) Sense of urgency to complete tasks; 6) Adapt and apply appropriate technology; 7) Dedication to continued professional development. 
Table A13. Experiences characteristic significant differences.

\begin{tabular}{|c|c|c|c|c|c|c|c|c|}
\hline \multicolumn{2}{|c|}{ Experiences } & \multirow{2}{*}{$\begin{array}{l}\text { Char.1 } \\
0.003\end{array}$} & \multirow{2}{*}{$\begin{array}{c}\text { Char.2 } \\
0.000\end{array}$} & \multirow{2}{*}{$\begin{array}{c}\text { Char.3 } \\
0.000\end{array}$} & \multirow{2}{*}{$\begin{array}{c}\text { Char.4 } \\
0.000\end{array}$} & \multirow{2}{*}{$\begin{array}{l}\text { Char.5 } \\
0.000\end{array}$} & \multirow{2}{*}{$\begin{array}{c}\text { Char.6 } \\
0.000\end{array}$} & \multirow{2}{*}{$\begin{array}{r}\text { Char.7 } \\
0.682\end{array}$} \\
\hline Ag. Services & Sig & & & & & & & \\
\hline & Wald & 8.907 & 121.751 & 13.562 & 44.084 & 20.677 & 31.753 & 0.168 \\
\hline & Std Err & 0.074 & 0.073 & 0.073 & 0.073 & 0.073 & 0.074 & 0.083 \\
\hline \multirow[t]{3}{*}{ Education } & Sig & 0.388 & 0.008 & 0.087 & 0.152 & 0.190 & 0.016 & 0.974 \\
\hline & Wald & 0.745 & 7.083 & 2.938 & 2.056 & 1.718 & 5.772 & 0.001 \\
\hline & Std Err & 0.074 & 0.073 & 0.073 & 0.073 & 0.073 & 0.073 & 0.083 \\
\hline \multirow[t]{3}{*}{$\begin{array}{l}\text { Product } \\
\text { Creation }\end{array}$} & Sig & 0.495 & 0.798 & 0.289 & 0.033 & 0.006 & 0.065 & 0.339 \\
\hline & Wald & 0.466 & 0.065 & 1.126 & 4.564 & 7.691 & 3.412 & 0.913 \\
\hline & Std Err & 0.116 & 0.116 & 0.116 & 0.115 & 0.116 & 0.116 & 0.135 \\
\hline \multirow[t]{3}{*}{ Government } & Sig & 0.010 & 0.000 & 0.566 & 0.000 & 0.556 & 0.513 & 0.011 \\
\hline & Wald & 6.607 & 29.778 & 0.330 & 25.679 & 0.347 & 0.428 & 6.463 \\
\hline & Std Err & 0.104 & 0.102 & 0.102 & 0.102 & 0.102 & 0.103 & 0.122 \\
\hline \multirow[t]{3}{*}{$\begin{array}{l}\text { Health } \\
\text { Services }\end{array}$} & Sig & 0.001 & 0.020 & 0.576 & 0.860 & 0.094 & 0.929 & 0.749 \\
\hline & Wald & 12.114 & 5.381 & 0.312 & 0.031 & 2.803 & 0.008 & 0.102 \\
\hline & Std Err & 0.080 & 0.078 & 0.078 & 0.078 & 0.078 & 0.079 & 0.089 \\
\hline \multirow[t]{3}{*}{$\begin{array}{l}\text { Service } \\
\text { Industry }\end{array}$} & Sig & 0.017 & 0.009 & 0.005 & 0.000 & 0.092 & 0.527 & 0.233 \\
\hline & Wald & 5.662 & 6.831 & 7.804 & 20.759 & 2.840 & 0.401 & 1.423 \\
\hline & Std Err & 0.082 & 0.080 & 0.080 & 0.080 & 0.080 & 0.081 & 0.091 \\
\hline \multirow[t]{3}{*}{ Other } & Sig & 0.523 & 0.000 & 0.160 & 0.172 & 0.278 & 0.873 & 0.004 \\
\hline & Wald & 5.662 & 12.307 & 1.973 & 1.863 & 1.175 & 0.026 & 8.139 \\
\hline & Std Err & 0.082 & 0.086 & 0.086 & 0.085 & 0.085 & 0.086 & 0.095 \\
\hline
\end{tabular}


Table A14. Teamwork characteristic significant differences.

\begin{tabular}{|c|c|c|c|c|c|c|c|c|}
\hline \multicolumn{2}{|c|}{ Team Skills } & \multirow{2}{*}{$\begin{array}{c}\text { Char.1 } \\
0.361\end{array}$} & \multirow{2}{*}{$\begin{array}{c}\text { Char.2 } \\
0.114\end{array}$} & \multirow{2}{*}{$\begin{array}{c}\text { Char.3 } \\
0.001\end{array}$} & \multirow{2}{*}{$\begin{array}{c}\text { Char.4 } \\
0.850\end{array}$} & \multirow{2}{*}{$\begin{array}{r}\text { Char.5 } \\
0.526\end{array}$} & \multirow{2}{*}{$\begin{array}{c}\text { Char.6 } \\
0.196\end{array}$} & \multirow{2}{*}{$\begin{array}{r}\text { Char.7 } \\
0.058\end{array}$} \\
\hline Ag. Services & Sig & & & & & & & \\
\hline & Wald & 0.836 & 2.501 & 10.630 & 0.036 & 0.403 & 1.676 & 3.604 \\
\hline & Std Err & 0.074 & 0.074 & 0.074 & 0.073 & 0.073 & 0.075 & 0.077 \\
\hline \multirow[t]{3}{*}{ Education } & Sig & 0.310 & 0.042 & 0.607 & 0.001 & 0.483 & 0.092 & 0.000 \\
\hline & Wald & 1.032 & 4.150 & 0.264 & 11.364 & 0.491 & 2.847 & 19.402 \\
\hline & Std Err & 0.074 & 0.074 & 0.073 & 0.073 & 0.074 & 0.075 & 0.076 \\
\hline \multirow[t]{3}{*}{$\begin{array}{l}\text { Product } \\
\text { Creation }\end{array}$} & Sig & 0.784 & 0.524 & 0.598 & 0.960 & 0.495 & 0.103 & 0.018 \\
\hline & Wald & 0.075 & 0.406 & 0.278 & 0.003 & 0.467 & 2.656 & 5.643 \\
\hline & Std Err & 0.119 & 0.118 & 0.118 & 0.117 & 0.117 & 0.120 & 0.125 \\
\hline \multirow[t]{3}{*}{ Government } & Sig & 0.778 & 0.705 & 0.493 & 0.844 & 0.847 & 0.082 & 0.523 \\
\hline & Wald & 0.080 & 0.144 & 0.470 & 0.039 & 0.037 & 3.022 & 0.408 \\
\hline & Std Err & 0.104 & 0.102 & 0.102 & 0.102 & 0.102 & 0.104 & 0.107 \\
\hline \multirow[t]{3}{*}{$\begin{array}{l}\text { Health } \\
\text { Services }\end{array}$} & Sig & 0.232 & 0.598 & 0.020 & 0.458 & 0.028 & 0.077 & 0.014 \\
\hline & Wald & 1.427 & 0.279 & 5.379 & 0.550 & 4.824 & 3.127 & 6.011 \\
\hline & Std Err & 0.080 & 0.079 & 0.079 & 0.079 & 0.079 & 0.080 & 0.081 \\
\hline \multirow[t]{3}{*}{$\begin{array}{l}\text { Service } \\
\text { Industry }\end{array}$} & Sig & 0.006 & 0.538 & 0.036 & 0.913 & 0.021 & 0.034 & 0.445 \\
\hline & Wald & 7.622 & 0.378 & 4.392 & 0.012 & 5.286 & 4.487 & 0.583 \\
\hline & Std Err & 0.082 & 0.081 & 0.081 & 0.081 & 0.081 & 0.082 & 0.084 \\
\hline \multirow[t]{3}{*}{ Other } & Sig & 0.520 & 0.256 & 0.988 & 0.381 & 0.285 & 0.371 & 0.001 \\
\hline & Wald & 0.410 & 1.292 & 0.000 & 0.767 & 1.142 & 0.801 & 10.384 \\
\hline & Std Err & 0.087 & 0.086 & 0.086 & 0.086 & 0.086 & 0.088 & 0.089 \\
\hline
\end{tabular}

significant B.E. LOWER PRIORITY than comparison field; significant B.E. HIGHER PRIORITY than comparison field. 1) Productive as a team member; 2) Punctual and meets deadlines; 3) Positive and encouraging attitude; 4) Maintains accountability to the team; 5) Work with multiple approaches; 6) Share ideas to multiple audiences; 7) Aware and sensitive to diversity. 
Table A15. Professionalism characteristic significant differences.

\begin{tabular}{|c|c|c|c|c|c|c|c|c|}
\hline \multicolumn{2}{|c|}{ Professionalism } & \multirow{2}{*}{$\begin{array}{l}\text { Char.1 } \\
0.792\end{array}$} & \multirow{2}{*}{$\begin{array}{c}\text { Char.2 } \\
0.041\end{array}$} & \multirow{2}{*}{$\begin{array}{c}\text { Char.3 } \\
0.021\end{array}$} & \multirow{2}{*}{$\begin{array}{c}\text { Char.4 } \\
0.767\end{array}$} & \multirow{2}{*}{$\begin{array}{c}\text { Char.5 } \\
0.660\end{array}$} & \multirow{2}{*}{$\begin{array}{c}\text { Char.6 } \\
0.675\end{array}$} & \multirow{2}{*}{$\begin{array}{r}\text { Char.7 } \\
0.028\end{array}$} \\
\hline Ag. Services & Sig & & & & & & & \\
\hline & Wald & 0.070 & 4.178 & 5.305 & 0.087 & 0.194 & 0.176 & 4.821 \\
\hline & Std Err & 0.076 & 0.075 & 0.075 & 0.075 & 0.076 & 0.076 & 0.076 \\
\hline \multirow[t]{3}{*}{ Education } & Sig & 0.006 & 0.828 & 0.000 & 0.636 & 0.711 & 0.193 & 0.075 \\
\hline & Wald & 7.473 & 0.047 & 15.344 & 0.224 & 0.137 & 1.696 & 3.175 \\
\hline & Std Err & 0.076 & 0.076 & 0.076 & 0.075 & 0.076 & 0.076 & 0.076 \\
\hline \multirow[t]{3}{*}{$\begin{array}{l}\text { Product } \\
\text { Creation }\end{array}$} & Sig & 0.214 & 0.065 & 0.998 & 0.492 & 0.368 & 0.015 & 0.440 \\
\hline & Wald & 1.545 & 3.415 & 0.000 & 0.473 & 0.809 & 5.869 & 0.596 \\
\hline & Std Err & 0.124 & 0.122 & 0.122 & 0.122 & 0.123 & 0.076 & 0.123 \\
\hline \multirow[t]{3}{*}{ Government } & Sig & 0.014 & 0.446 & 0.058 & 0.145 & 0.423 & 0.000 & 0.532 \\
\hline & Wald & 5.999 & 0.580 & 3.594 & 2.119 & 0.643 & 14.595 & 0.390 \\
\hline & Std Err & 0.106 & 0.105 & 0.105 & 0.104 & 0.105 & 0.106 & 0.105 \\
\hline \multirow[t]{3}{*}{$\begin{array}{l}\text { Health } \\
\text { Services }\end{array}$} & Sig & 0.728 & 0.130 & 0.002 & 0.272 & 0.077 & 0.092 & 0.000 \\
\hline & Wald & 0.121 & 2.289 & 9.149 & 1.206 & 3.137 & 2.833 & 20.001 \\
\hline & Std Err & 0.082 & 0.081 & 0.081 & 0.081 & 0.081 & 0.082 & 0.082 \\
\hline \multirow[t]{3}{*}{$\begin{array}{l}\text { Service } \\
\text { Industry }\end{array}$} & Sig & 0.000 & 0.000 & 0.000 & 0.075 & 0.825 & 0.079 & 0.051 \\
\hline & Wald & 19.181 & 16.977 & 27.437 & 3.165 & 0.049 & 3.090 & 3.808 \\
\hline & Std Err & 0.086 & 0.084 & 0.084 & 0.084 & 0.084 & 0.084 & 0.085 \\
\hline \multirow[t]{3}{*}{ Other } & Sig & 0.302 & 0.315 & 0.516 & 0.141 & 0.469 & 0.066 & 0.965 \\
\hline & Wald & 1.066 & 1.009 & 0.421 & 2.171 & 0.525 & 3.382 & 0.002 \\
\hline & Std Err & 0.091 & 0.090 & 0.090 & 0.089 & 0.090 & 0.090 & 0.090 \\
\hline
\end{tabular}

significant B.E. LOWER PRIORITY than comparison field;

significant B.E. HIGHER PRIORITY than comparison field.

1) Effective relationships with customers, businesses and the public; 2) Accept critique and direction in the work place; 3) Trustworthy with sensitive information; 4) Understand role, realistic career expectations; 5) Maintain appropriate decor and demeanor; 6) Select mentor and acceptance of advice; 7) Deal effectively with ambiguity. 
Table A16. Leadership characteristic significant differences.

\begin{tabular}{|c|c|c|c|c|c|c|c|c|}
\hline \multicolumn{2}{|c|}{ Leadership } & \multirow{2}{*}{$\begin{array}{l}\text { Char.1 } \\
0.915\end{array}$} & \multirow{2}{*}{$\begin{array}{c}\text { Char.2 } \\
0.174\end{array}$} & \multirow{2}{*}{$\begin{array}{c}\text { Char.3 } \\
0.154\end{array}$} & \multirow{2}{*}{$\begin{array}{c}\text { Char.4 } \\
0.258\end{array}$} & \multirow{2}{*}{$\begin{array}{c}\text { Char.5 } \\
0.882\end{array}$} & \multirow{2}{*}{$\begin{array}{c}\text { Char.6 } \\
0.046\end{array}$} & \multirow{2}{*}{$\begin{array}{r}\text { Char.7 } \\
0.009\end{array}$} \\
\hline Ag. Services & Sig & & & & & & & \\
\hline & Wald & 0.011 & 1.846 & 2.033 & 1.282 & 0.022 & 3.993 & 6.854 \\
\hline & Std Err & 0.075 & 0.074 & 0.074 & 0.074 & 0.074 & 0.074 & 0.075 \\
\hline \multirow[t]{3}{*}{ Education } & Sig & 0.004 & 0.702 & 0.264 & 0.643 & 0.732 & 0.324 & 0.015 \\
\hline & Wald & 8.273 & 0.147 & 1.248 & 0.215 & 0.117 & 0.974 & 5.893 \\
\hline & Std Err & 0.075 & 0.074 & 0.074 & 0.074 & 0.074 & 0.074 & 0.075 \\
\hline \multirow[t]{3}{*}{$\begin{array}{l}\text { Product } \\
\text { Creation }\end{array}$} & Sig & 0.295 & 0.755 & 0.574 & 0.166 & 0.023 & 0.101 & 0.003 \\
\hline & Wald & 1.096 & 0.098 & 0.316 & 1.916 & 5.203 & 2.696 & 8.751 \\
\hline & Std Err & 0.121 & 0.120 & 0.120 & 0.120 & 0.120 & 0.120 & 0.121 \\
\hline \multirow[t]{3}{*}{ Government } & Sig & 0.082 & 0.167 & 0.030 & 0.670 & 0.007 & 0.030 & 0.686 \\
\hline & Wald & 3.018 & 1.909 & 4.731 & 0.181 & 7.275 & 4.715 & 0.164 \\
\hline & Std Err & 0.104 & 0.103 & 0.103 & 0.103 & 0.104 & 0.103 & 0.105 \\
\hline \multirow[t]{3}{*}{$\begin{array}{c}\text { Health } \\
\text { Services }\end{array}$} & Sig & 0.234 & 0.999 & 0.496 & 0.523 & 0.007 & 0.783 & 0.016 \\
\hline & Wald & 1.418 & 0.000 & 0.464 & 0.407 & 7.249 & 0.076 & 5.823 \\
\hline & Std Err & 0.080 & 0.080 & 0.080 & 0.080 & 0.080 & 0.080 & 0.081 \\
\hline \multirow[t]{3}{*}{$\begin{array}{l}\text { Service } \\
\text { Industry }\end{array}$} & Sig & 0.030 & 0.491 & 0.356 & 0.000 & 0.778 & 0.000 & 0.004 \\
\hline & Wald & 4.689 & 0.475 & 0.851 & 14.029 & 0.079 & 24.813 & 8.330 \\
\hline & Std Err & 0.083 & 0.082 & 0.082 & 0.082 & 0.082 & 0.082 & 0.083 \\
\hline \multirow[t]{3}{*}{ Other } & Sig & 0.004 & 0.313 & 0.854 & 0.945 & 0.536 & 0.445 & 0.098 \\
\hline & Wald & 8.229 & 1.019 & 0.034 & 0.005 & 0.382 & 0.583 & 2.733 \\
\hline & Std Err & 0.088 & 0.088 & 0.088 & 0.088 & 0.088 & 0.088 & 0.089 \\
\hline
\end{tabular}

significant B.E. LOWER PRIORITY than comparison field;

significant B.E. HIGHER PRIORITY than comparison field 1) See the "big picture" and think strategically; 2) Recognize when to lead and when to follow; 3) Recognize and deal constructively with conflict; 4) Respect and acknowledge others contributions; 5) Motivate and lead others; 6) Build professional relationships; 7) Recognize change is needed and lead the change effort. 